\title{
¿ARs SubTilior en Toledo? \\ Un vestigio en el Códice M1361 de la Biblioteca Nacional de España
}

\author{
Ars SUbTILIOR IN TOLEDo? \\ A Hint in the Manuscript M1361 of the Biblioteca Nacional de España
}

\author{
David Catalunya \\ Universität Würzburg
}

\begin{abstract}
Resumen:
El presente estudio analiza uno de los escasos testimonios musicales de origen hispánico relacionados con la práctica del Ars Subtilior. El fragmento en cuestión, conservado en folios residuales de un códice litúrgico (M1361), consiste en una amplificación polifónica del Amen de un Credo monódico. El manuscrito es examinado desde diferentes ángulos aclarando cuestiones como el origen del códice, la identidad de su escriba principal y arrojando nueva luz acerca del fragmento subtilior. El análisis de su proceso escriturario sugiere una conexión entre la boga subtilior y la práctica de improvisar biscanti sobre tenores litúrgicos. El autor revisa también otras fuentes hispánicas clasificadas de manera imprecisa en la literatura musicológica como Ars subtilior a causa de transcripciones erróneas.
\end{abstract}

\section{Palabras clave:}

Siglo XIV; polifonía; Ars nova; Ars subtilior; improvisación; Toledo; codicología; paleografía; restauración digital.

\begin{abstract}
:
The present article analyzes the case of the manuscript M1361, a liturgical codex containing in its residual folios one of the very few Spanish musical witnesses showing Ars Subtilior features. The subtilior setting consists of a polyphonic amplification for the Amen of a monophonic Credo. M1361 is examined from different angles, clarifying the origin of the book, the identity of its main scribe, and offering a new fresh interpretation of the Ars Subtilior fragment; the analysis of its writing process suggests a connection between the Ars Subtilior fashion and the practice of improvising biscanti on liturgical tenores. The author also reviews other Spanish sources wrongly cited in musicological literature as Ars subtilior due to erroneous transcriptions.
\end{abstract}

\section{Key words:}

$14^{\text {th }}$-century; Ars nova; Ars subtilior; improvisation; Toledo; codicology; palaeography; digital restoration. 
El Ars subtilior ${ }^{1}$ irrumpe en la historia de la música hispánica con un capítulo lleno de lagunas e interrogantes. Si bien es sabido que Senleches -uno de los compositores más brillantes e innovadores del Ars subtilior - forjó parte importante de su carrera en la Península Ibérica, la falta de fuentes musicales de origen hispánico relacionadas con esta flamante vanguardia musical de finales del siglo XIV supone para los investigadores un auténtico quebradero de cabeza. Según parece, Jacob de Senleches estuvo al servicio de doña Leonor de Aragón, Reina de Castilla, a quien dedico la célebre ballade "Fuions de ci" con motivo de su óbito en 1382. ${ }^{2}$ En 1383, Senleches está documentado en la Casa Real de Navarra, recibiendo un pago para que pudiese regresar al servicio de su nuevo protector, el cardenal aragonés Pedro de Luna (futuro papa Benedicto XIII). ${ }^{3}$ No obstante, resulta intrigante el hecho de que la obra de Senleches haya sobrevivido únicamente a través de códices derivados de Francia e Italia. ${ }^{4}$ Las fragmentarias fuentes españolas de este periodo transmiten fundamentalmente repertorio sacro en el "clásico" estilo del Ars nova.

Ante un panorama tan lacónico, resulta difícil y arriesgado atreverse a valorar cuál fue el verdadero impacto del Ars subtilior en los antiguos reinos hispánicos. Demasiadas son las incógnitas en torno a sus vías de difusión y su grado de asimilación en la Península Ibérica. En consecuencia, cualquier indicio que pudiera aportar alguna información al respecto debería ser analizado con la máxima atención. Sin embargo, el ejemplo quizás más significativo de la práctica del Ars subtilior en tierras hispánicas (anotado en un folio residual de un códice litúrgico de la Biblioteca Nacional de Madrid, M1361 f. 178v) ha sido citado, hasta el momento, de manera imprecisa y superficial. ${ }^{5}$

\footnotetext{
* Quiero agradecer a mis colegas por las valiosas discusiones académicas, comentarios y sugerencias sobre el último borrador de este artículo, especialmente a mis queridos amigos Juan Carlos Asensio, Jason Stoessel, Pedro Memelsdorff, Carmelo Caballero y Carmen Julia Gutiérrez.

1 Con 'Ars subtilior', término introducido en el vocabulario musicológico por Ursula Günther (véase GüNTHER, Ursula: "Das Ende der Ars Nova”, en Die Musikforschung, 1963, vol. 16, pp 105-20), me refiero al estilo musical de finales del siglo xIV caracterizado por una exploración rítmica que sobrepasa y transgrede los principios tradicionales del sistema notacional arsnovístico. Para plasmar tal flexibilidad agógica, compositores y escribas emplearon diversos métodos notacionales que incluían la invención de nuevas formas de notas, coloración, evacuación, el uso de números y otros signos proporcionales, pero también el uso de signos tradicionales a los que se les imprimió un significado inconvencional. Entre los más recientes estudios sobre la notación del Ars subtilior cabe señalar aquí las disertaciones de StoEssel, Jason: The Captive Scribe: The Context and Culture of Scribal and Notational Process in the Music of he Ars Subtilior. University of New England, 2002 (Tesis Doctoral); y STONE, Anne: Writing rhythm in late medieval Italy: Notation and musical style in the manuscript Modena, Biblioteca Estense, $\alpha . M .5 .24$. Harvard University, 1994 (Tesis Doctoral).

2 Fuions de ci viene transmitida en tres de los códices más significativos del Ars subtilior: Chantilly, Bibliothèque du Musée Condé MS 564, f. 17r; Modena, Biblioteca Estense a.M.5.24 (Mod A), ff. 15v-16r; y Paris, Bibliothèque Nationale, fonds nouv. acq. français 6771 (Codex Reina), f. 61v. En el texto de esta ballade, Senleches se lamenta del óbito de la reina y aconseja a sus colegas que busquen trabajo en Aragón, en Francia o en Bretaña, puesto que nadie se ocuparía de ellos como lo hizo Doña Leonor. La biografía de Senleches ha sido recientemente discutida en Plumley, Yolanda; Stone, Anne: Codex Chantilly, Bibliothèque du Chaâteau de Chantilly Ms. 564. Introduction [Introducción a la edición facsímile]. Épitome Musical, Brepols, Turnhout, 2008.

3 Anglés, Higini: Historia de la música medieval en Navarra. Pamplona, Aranzadi, 1970, p. 225.

4 La obra de Senleches es actualmente conocida a través de seis manuscritos: los anteriormente citados Chantilly, Modena y Reina además de Chicago, Newberry Library 54.1; Padua, Biblioteca Universitaria 1115 B; y Strasbourg, Bibliothèque Municipale $222 \mathrm{C}$ (perdido).

5 Madrid, Biblioteca Nacional de España, M1361, f. 178. Citado por Anglés, Harder, Reaney, Gómez y Kügle, entre otros. La historiografía de este ejemplo musical y el códice que lo transmite es analizada en los siguientes apartados.
} 
Se trata de un pequeño fragmento sin texto que llama la atención por condensar en apenas una línea los artificios notacionales más complejos jamás encontrados en ninguna otra fuente de origen hispánico. El fragmento en cuestión pasa por cuatro proporciones distintas, para lo cual el escriba se sirvió de signos proporcionales (números arábigos '3’ y ‘4’) y del signo mensural ๔. Su figuración rítmica es variada, ágil, fluida, y usa valores hasta la semiminima. Además, el Credo monódico que inmediatamente le precede, copiado por la misma mano, presenta una interesante combinación de notación negra, figurae vacue y extensos pasajes en coloración roja. Características notacionales todas ellas (junto con los signos proporcionales) asociadas al estilo subtilior de finales del siglo xIv.

El mencionado Credo y su "fragmento sin texto" se convierten pues en la evidencia musical de origen hispánico más próxima al Ars subtilior actualmente conocida. ${ }^{6}$ Un estudio minucioso sobre este testimonio tal vez logre aportar nuevas pistas acerca de un episodio todavía borroso en la historia de la música tardo medieval.

6 Otro ejemplo que deja ver tímidas influencias del Ars subtilior es un Kyrie conservado en el manuscrito fragmentario M853, de la Biblioteca Nacional de Cataluña (f. 2v). Analizo brevemente el caso de este Kyrie en el Anexo II de este estudio. Maricarmen Gómez cita en su libro La música medieval en España. Kassel, Reichenberger, 2001, el Amen de un Credo conservado en el manuscrito M853d de la Biblioteca de Nacional de Cataluña, f. 2r, "cuya complejidad rítmica hace que se clasifique en el Ars subtilior", p. 251. Desafortunadamente, no podemos tomar en consideración este Amen, ya que la opinión de Gómez está basada en una transcripción errónea (Polyphonic Music of the Fourteenth Century. Monaco, Editions de l'Oiseau Lyre, 1992, vol. 23B French Sacred Music (PMFC XXIIIB), pp. 303-306). El problema es analizado en el Anexo II de este artículo. 


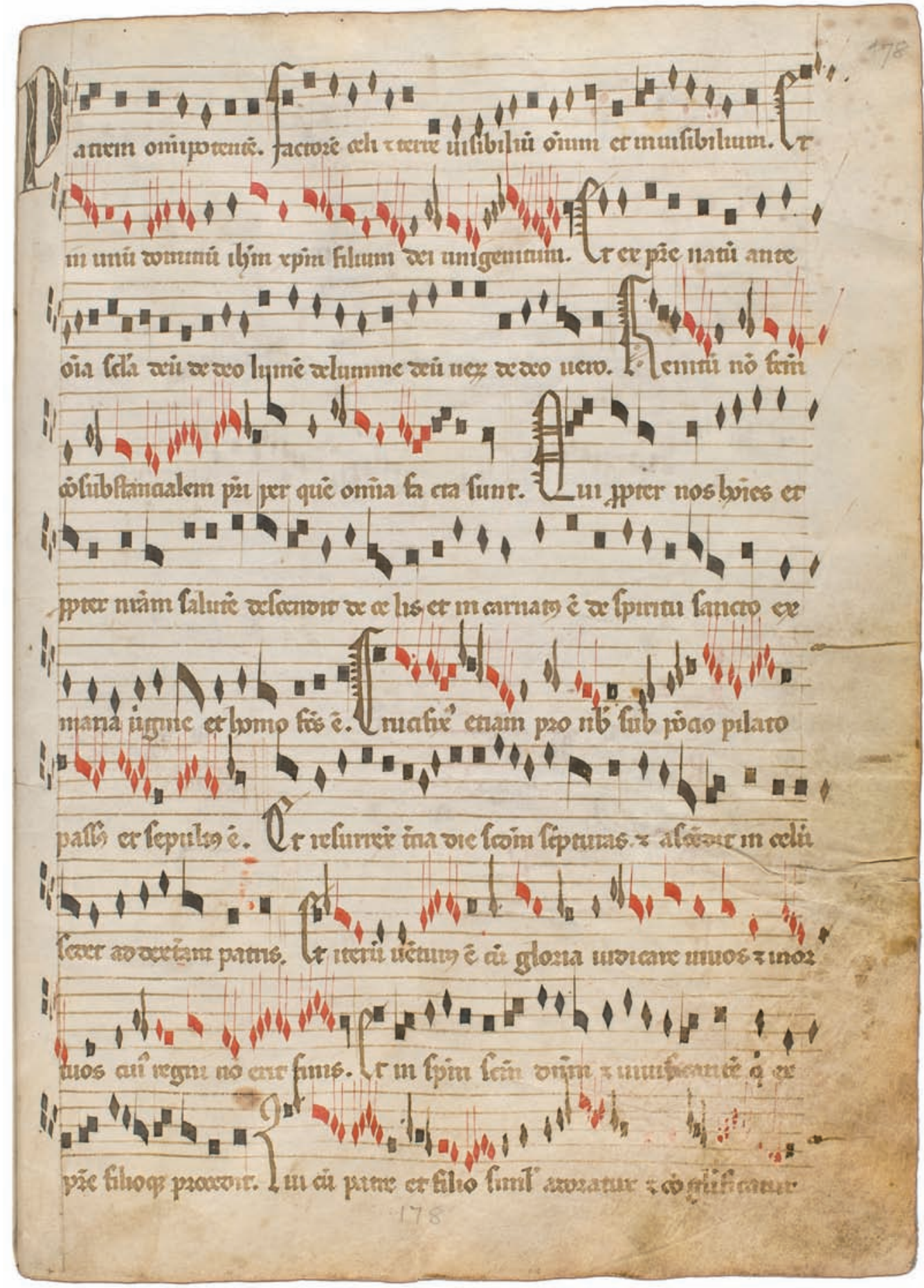

Figura 1. M1361 f. 178r, Credo (Patrem omnipotentem) 


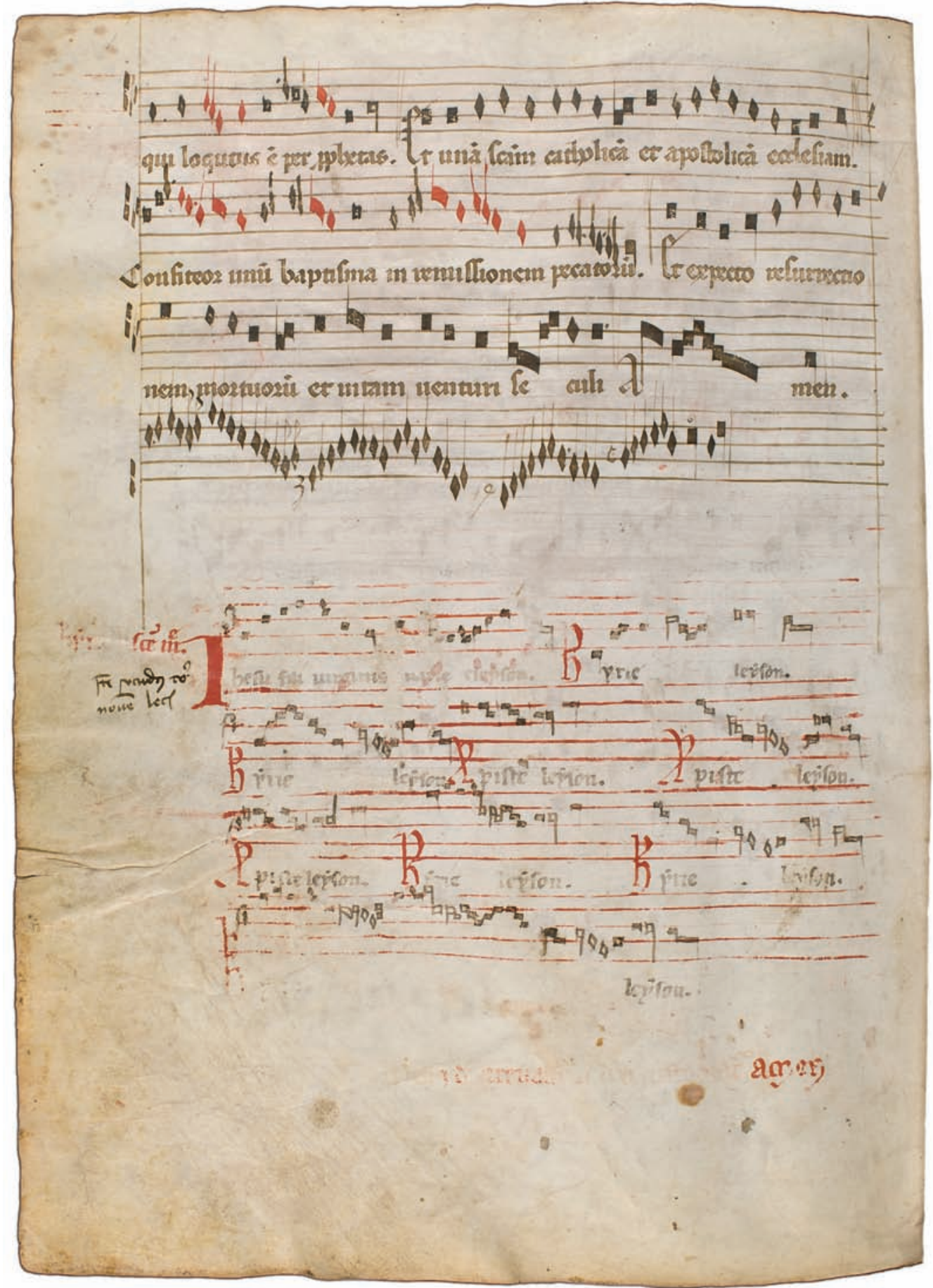

Figura 2. M1361 f. 178v (continuación del Credo) 


\section{EL MANUSCRITO M1361 DE MADRID. REVISIÓN CODICOLÓGICA}

El códice M1361 de la Biblioteca Nacional de Madrid es un precioso Gradual de principios del siglo XIV de origen monástico. ${ }^{7}$ Aunque su encuadernación ha sido restaurada modernamente, sus 199 folios ${ }^{8}$ siguen custodiados por una hermosa cubierta mudéjar de piel sobre madera que debe datar del siglo XV o XVI. ${ }^{9}$ La esmerada elaboración de su copia, así como la calidad del pergamino utilizado, lo convierte en un objeto de cuantioso valor. El abundante espacio dejado para la miniatura de iniciales denota un proyecto de gran envergadura, indicativo también de la importancia de su comitente.

Hasta el presente, M1361 ha sido descrito y citado en numerosas ocasiones. Ya en 1931 Higinio Anglés se refería a él en su introducción al Códice de las Huelgas. ${ }^{10}$ Más tarde, fue descrito en el Catálogo Musical de la Biblioteca Nacional de Madrid (H. Anglés 1946-51), en el RISM (G. Reaney, 1969) y en Manuscritos litúrgicos de la Biblioteca Nacional (J. Janini, 1969). En 1991 Maricarmen Gómez Muntané publicó un artículo monográfico con una nueva descripción detallada y revisada en la que corrigió errores de identificación y catalogación de algunas piezas polifónicas y aportó valiosos datos sobre los diversos escribas que intervinieron en la copia. ${ }^{11}$ A la preciada contribución de Gómez Muntané cabe, sin embargo, añadir nuevas observaciones pertinentes para nuestro estudio. Con este fin, seguiré la nomenclatura que Gómez propuso para la identificación de los distintos escribas.

\subsection{COMPILACIÓN DEL CORPUS PRINCIPAL}

El corpus principal de M1361 consta de veintidós fascículos quiniones ${ }^{12}$ que fueron copiados fundamentalmente por un mismo escriba, al que Gómez denomina “mano A”. La continuidad del contenido entre los fascículos indica que la copia se realizó linealmente (salvo una excepción). Los fascículos vienen sistemáticamente marcados con reclamos, ${ }^{13}$ cuya inscripción en posición vertical cerca del pliegue parece haber sido una característica específica de scriptoria castellanos. ${ }^{14}$ La homogeneidad de la escritura y la

7 El origen y la procedencia del manuscrito son estudiados en el siguiente apartado. Según Anglés, este Graduale es de origen monástico, puesto que en ocasiones aparecen mencionadas las "XII lectiones". Anglés, Higini: Catálogo Musical de la Biblioteca Nacional de Madrid. Barcelona, Instituto Español de Musicología-csic, 1946-51, p. 100.

$8290 \times 215 \mathrm{~mm}$, lo que equivale a un formato inquarto.

9 Encuadernación de tabla recubierta de cuero sobrepujado con decoración gofrada (técnica por impresión de hilos y hieros en seco), cierre de metal y corré́lla. Cobertura, encuadernación y códice fueron restaurados en la Biblioteca Nacional después de 1969, puesto que Janini dice en su descripción que "En las guardas pegadas a las cubiertas, [hay] dos hojas de un Breviario (s. XII, fines), con notación aquitana" y actualmente éstas no se encuentran formando parte de la encuadernación. JANINI, José: Manuscritos litúrgicos de la Biblioteca Nacional. Madrid, Dirección General de Archivos y Bibliotecas, 1969, p. 284.

10 Anglés, Higini: El Còdex Musical de Las Huelgas. Barcelona, Institut d’Estudis Catalans, 1931, vol. I.

11 Gómez Muntané, Maricarmen: "Autour du répertoire du XIVe siècle du manuscrit M1361 de la Bibliothèque Nationale de Madrid" en Aspects de la Musique liturgique au Moyen Age. Paris, Créaphis, 1991, pp. 245-260 (reeditado en L'Ars nova italiana del Trecento. Certaldo, Centro di Studi sull'Ars Nova Italiana del Trecento, 1992, vol. vI, pp. 193-207).

12 Fascículos (cuadernillos) constituidos por cinco bifolios (diez folios). Algunos fascículos perdieron folios durante el proceso de compilación. Otros folios fueron arrancados posteriormente.

13 Pequeña marca inscrita al final de cada fascículo citando la continuación del texto para orientar su correcta ordenación en el momento de la encuadernación.

14 Sobre el uso de reclamos verticales véase RodRíGEZ, E.: "El uso de reclamos en España: reinos occidentales" en Scriptorium, 1999, vol. 53/1, pp. 3-30. 
decoración observada a lo largo de todo el códice demuestra una labor refinada y de gran profesionalidad. $\mathrm{Su}$ compilación fue un trabajo bien planificado y realizado con cierta rapidez, sin traumas importantes.

El escriba A utiliza una notación cuadrada fechable a finales del siglo XIII o principios del siglo XIV, caracterizada por una abundante presencia de plicae y de pequeños trazos verticales para separar los melismas por palabras o por frases. El ductus de su caligrafía musical deja ver una fuerte influencia aquitana. De hecho, en varias ocasiones aparecen citados incipits de melodías con neumas aquitanos. ${ }^{15}$ Este tipo de notación cuadrada tiene rasgos comunes con, por ejemplo, el manuscrito Madrid 20486 (S. XIII, polifonía de la llamada 'escuela de Notre Dame'), que fue propiedad de la Catedral de Toledo hasta el año 1869. ${ }^{16}$

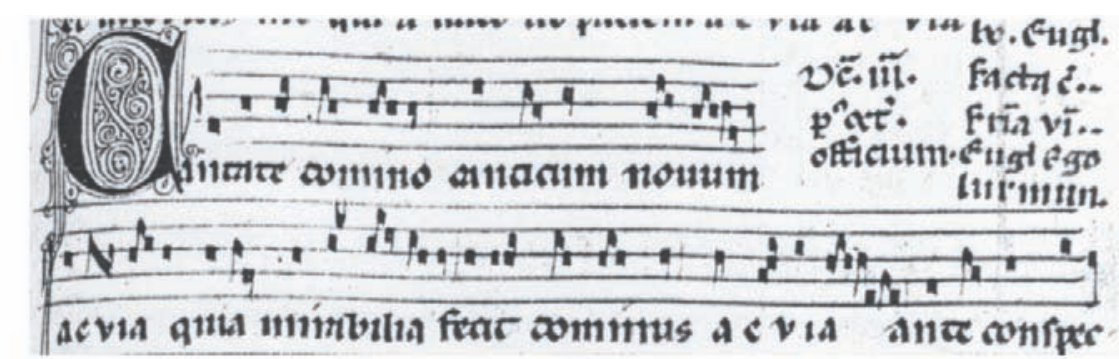

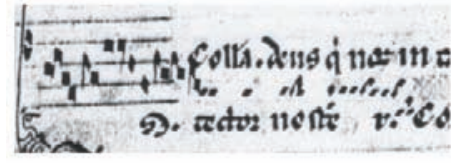

f. $34 \mathrm{v}$

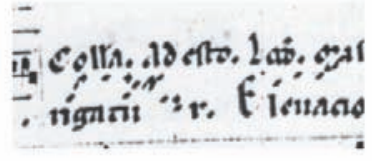

f. $35 \mathrm{r}$

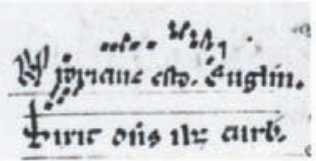

f. $41 v$

Figura 3. Notación musical del escriba A
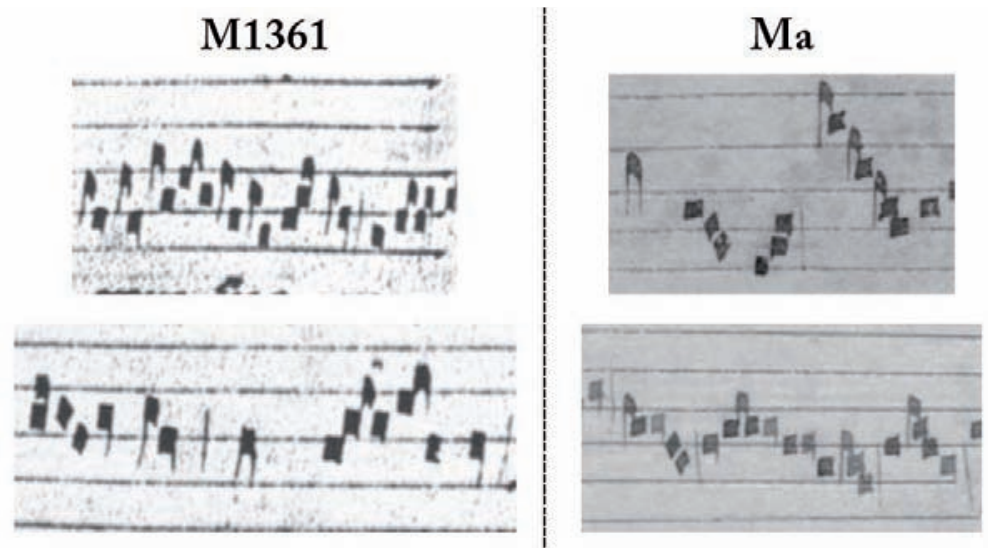

Figura 4. Comparación de las notaciones de M1361 y MA

15 ff. 34v, 35r, 39r, 40r, 41v, 90v, 91v.

16 Madrid, Biblioteca Nacional de España MS 20486, también conocido como "Códice de Madrid" (Ma). Sobre la historia antigua de este códice véase Asensio, Juan Carlos: El códice de Madrid, Biblioteca Nacional Ms 20486: Polifonías del siglo xIII. Madrid, Fundación Caja Madrid, 1997. 

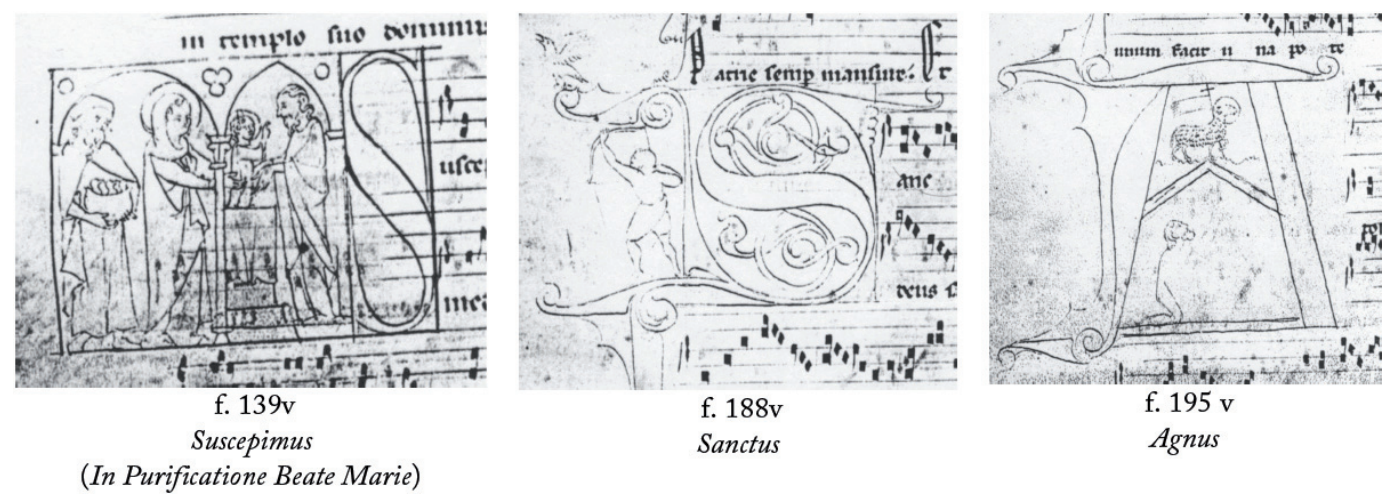

Figura 5. M1361, Bocetos para la miniatura

En líneas muy generales, el contenido de M1361 se organiza de la siguiente manera:

Fascículos I-xx $\quad \cdot$ Temporal (ff. 2r-135r) (ff. 2-178)

- Santoral (ff. 136r-152r)

· Común de santos (152v-176v)
Desde la dominica I de adviento hasta la dominica 23 post Pentecostes.

f. $135 \mathrm{v}$ en blanco.

Desde "In nat. S. Stephani prothomartiris" hasta la Traslación de san Isidoro.

Rúbrica: "In comunitate sanctorum. Officia" ff. 177-178 originalmente vacíos.

Kyrie tropados; Gloria tropados; Sanctus tropados; Agnus; Ite missa est.

ff. 196v-197 originalmente vacíos

(excepto mitad superior de 197r).

La foliación original acaba en el folio $176 \mathrm{v}$ con la cifra clxxxvii. ${ }^{17}$ Los dos siguientes folios, 177 178, que son los dos últimos del fascículo xx, quedaron originalmente en blanco. Esto sugiere que los fascículos XXI y xxII, destinados al ordinario de la misa, y que no vienen foliados, pudieron ser añadidos al códice en una fase posterior.

Si bien el intervalo de tiempo no debió ser muy extenso, la idea de que el códice fue confeccionado en dos etapas viene además reforzada por una inscripción roja parcialmente raspada en la parte inferior del último verso del fascículo xx (178v): "Petrus de arevalo ... amen" ${ }^{18}$ Gómez se inclina a pensar que esta inscripción pueda ser la signatura de uno de los escribas secundarios, al que denomina $\beta .{ }^{19}$ Sin embargo, la

17 Faltan 11 folios.

18 Arévalo es una pequeña localidad castellana de origen medieval, situada a unos 50 kilómetros de Ávila. Según Gómez Muntané (1991) ningún centro religioso de importancia puede justificar allí la presencia del manuscrito, lo que hace pensar que ese tal Petrus de Arévalo debió haber trabajado en algún otro lugar.

19 El argumento que Gómez expone es la comparación de una sola letra (que además es una letra capital!): "La ressemblance de la $P$ initiale de 'Petrus' avec celle par laquelle débute le texte du Credo qui précède l'inscription (fol. 178) -'Patrem'- 
comparación de los caracteres 'd', 'a', 'e', 'u', 'r' aún visibles en la inscripción de 178v con la caligrafía de A (especialmente con sus rúbricas rojas encontradas a lo largo de todo el códice) me lleva a pensar claramente en la mano del copista principal A. La aplicación de tecnología digital avanzada me ha permitido reconstruir el segmento de la inscripción ilegible a simple vista y publicar aquí su restauración virtual. ${ }^{20 ~ " P e t r u s ~ d e ~ a r e-~}$ valo a $b$ deo custodiatur amen" es una fórmula característica de signaturas conclusivas o colophon.

Otro colophon de A al final del códice (f. 197v, último verso del fascículo xxII), que Gómez no observó, confirma el hábito de este copista de situar sus signaturas en el último verso del fascículo, aún cuando los últimos folios pudieran haber quedado vacíos. La parte legible de la inscripción del f. 197v, "petrus (are)...s s...ipsit", nos lleva a la fórmula "petrus [de] arevalus [me] scripsit".

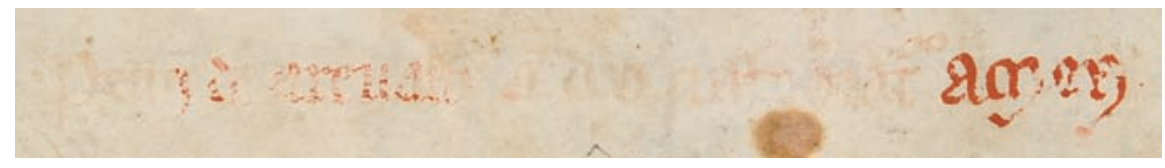

f. 178v. Colophon escriba A, fotografía digital

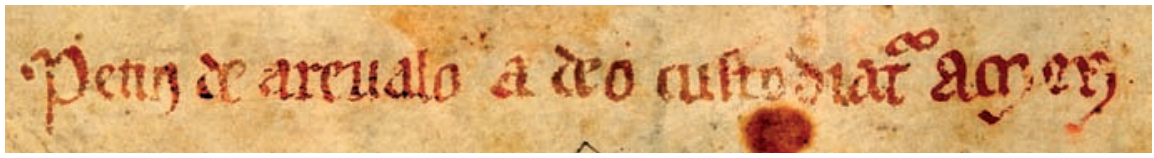

Restauración digital

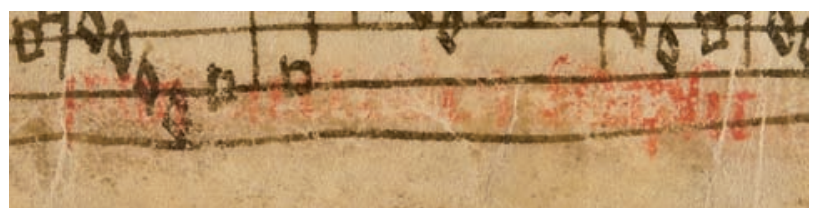

f. 197v. Colophon escriba A

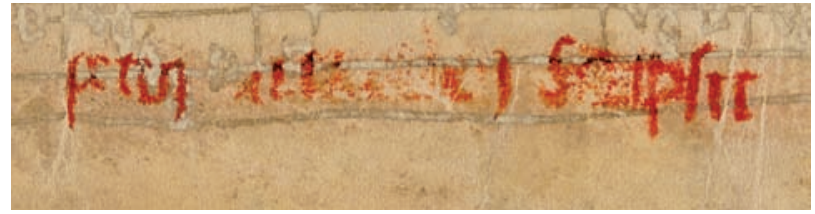

Restauración digital

Figura 6. Colophon del Escriba A en el los folios 178v Y 197v

m'incline à penser qu'il s'agit du copiste qui écrit celui-ci, c'est à dire, la main que nous avons dénommé $\beta$ ”. GómEz MunTANÉ, Maricarmen: op. cit. 1991, p. 248 [aquí cito la versión de 1992 en L'Ars nova italiana del Trecento vI, p. 196].

20 Digitalización realizada en octubre del 2009. Agradezco la preciadísima cooperación de Félix González, responsable del Servicio de Digitalización de la Biblioteca Nacional de España, quien atendió con mucha atención los requerimientos especiales de esta digitalización. 
La ampliación del códice con dos nuevos fascículos del ordinarium missae debió suponer un cambio en el plan original. Si los veinte primeros fascículos no estaban ya encuadernados en ese momento, al menos sí habían sido paginados. No obstante, el nuevo programa de confección siguió la misma línea con total coherencia, aunque quizás con ambiciones menos lujosas. En estos dos últimos fascículos, son solamente dos los espacios reservados a la miniatura de iniciales. ${ }^{21}$ Una vez el artesano miniaturista hubo empezado a trabajar en la decoración, un posterior giro en la historia del códice dejó incompleta su labor. ${ }^{22}$

Múltiples señales de uso, correcciones, adiciones y anotaciones marginales dejan ver que este libro tuvo una larga vida útil a lo largo de los siglos.

\subsection{Adiciones posteriores. El escriba $\beta$ y SU ENTORNo}

Los folios residuales que quedaron al final de los fascículos Xx y xxII fueron utilizados durante el siglo XIV y principios del siglo XV para anotar diversas piezas polifónicas y monódicas, al menos por seis o siete escribas distintos. Entre las adiciones efectuadas figura además la anexión de un bifolio al final del códice (ff. 189-199). ${ }^{23}$

La diversidad de estilos y notaciones testimoniada en un periodo de tiempo relativamente breve es sorprendente. Tendencias vanguardistas y rasgos arcaizantes aparecen amalgamados en una compleja red de influencias estilísticas, a veces incluso dentro de una misma pieza.

El dato para nosotros relevante concierne a la actividad del escriba denominado $\beta$, cuya mano anotó el Credo y el fragmento subtilior del folio $178 \mathrm{r}-\mathrm{v} .{ }^{24}$ Tal como Gómez indicó, $\beta$ es también responsable de

21 No es absolutamente descartable que estos dos últimos fascículos hayan pertenecido a otro libro elaborado por el mismo copista. Sin embargo, el hecho que el primer recto del fascículo Xxi no reserve espacio para miniatura y, sobre todo, la homogeneidad de la caja de texto con respecto al resto del códice y la absoluta coherencia de formato, caja de texto y mise en page me hacen suponer que los dos fascículos fueron concebidos como una ampliación del códice.

22 En la mayoría de los casos sólo queda el espacio destinado a la decoración; las miniaturas que fueron completadas fueron recortadas en siglos posteriores. Los folios 139v, 188v y 195v contienen bocetos de miniaturas incompletas, que dan una idea del tipo de miniatura planificada (iniciales historiadas). Los dibujos se extienden a veces por los márgenes.

23 Las dimensiones de este bifolio (ff. 189-199) son ligeramente menores que el resto del códice, y la calidad del pergamino es notablemente inferior; no parece haber sido preparado (pulido) para recibir escritura. En la mitad superior de 198r hay un fragmento musical palimpsesto en notación cuadrada negra (digitalmente restaurado en el Anexo I de este estudio). En el último verso (en blanco) se observan pequeños restos de notación musical blanca y lo que parece haber sido la decoración de una letra inicial que, sin embargo, no son palimpsestos; parecen más bien marcas de 'doble espejo' (tinta transferida de un folio a otro dos veces). Este hecho, junto con la baja calidad del pergamino, me hace pensar que el bifolio servía de guarda en algún otro manuscrito antes de ser utilizado para copiar el Gloria polifónico; en todo caso parece improbable que el bifolio originalmente haya formado parte de un fascículo mayor o un códice de polifonía. Que este bifolio ya formaba parte de M1361 a principios del s. $\mathrm{xv}$ se deduce fácilmente por una pieza a tres voces (Adoramus te Christe) que cruza la apertura formada entre el último verso del último fascículo y el primer recto del bifolio. Numerosas marcas de tinta 'en espejo' (causadas por el pliegue del bifolio cuando la tinta aún no estaba aún seca) dificultan la lectura de algunos pasajes en la apertura interna.

24 El Credo en cuestión (f. 178r-v) es una composición monódica mensural que parafrasea al Credo I del Graduale Romanum. Para completar su trabajo, $\beta$ tuvo que borrar música de otro escriba secundario que previamente había ocupado el verso del folio 178v. Solamente el Kyrie Ihesu fili virginis (mitad inferior de la página) escapó al raspado de $\beta$. El hecho de que $\beta$ haya necesitado raspar la mitad superior del f. $178 \mathrm{v}$ delata el especial interés de $\beta$ en anotar su versión del Credo en ese preciso folio, justo al lado del otro Credo copiado por otro escriba $(\alpha)$ en el f. 177r-v (al que $\beta$ añade minimae). 
la copia de Iuste iudex (f. 196v) ${ }^{25}$ y de la adición de minimae en otro Credo monódico mensural (previamente copiado por otra mano) en el f. $177 \mathrm{r}-\mathrm{v}^{26}$

La apertura interna del bifolio anexo al final del códice contiene un Gloria polifónico (Et in terra) a tres voces sin correspondencias conocidas. ${ }^{27}$ Según Gómez, este Gloria fue copiado por otro escriba, al que denomina $\delta$. La caligrafía textual de este Gloria es cursiva, mientras que la caligrafía de las piezas que Gómez atribuye a $\beta$ es una gótica libraria. Su comparación grafológica resulta por tanto inviable. Este hecho, junto con las diferencias en el pautado, la calidad del pergamino y el estado de conservación del bifolio, otorga al Gloria una apariencia a primera vista muy diferente del resto de piezas copiadas por $\beta$. Sin embargo, una mirada atenta a la caligrafía musical, que sí admite comparación, muestra semejanzas del todo reveladoras.

El espesor de las notas, la longitud e inclinación de las caudas, la clave de ut, bemoles, custodes, signum congruentiae, etc... Si no fuera por un mínimo detalle en el ductus de las figuras romboidales (que quizás pueda deberse al uso de una pluma diferente) todo parecería indicar que el escriba del Gloria es el mismo escriba $\beta$ usando esta vez caligrafía cursiva. Además, la tinta, de un tono marrón característico, es prácticamente idéntica en las tres piezas (Gloria, Credo y Iuste iudex). Si no se trata de la misma persona, el copista del Gloria debió ser un escriba realmente cercano al entorno de $\beta$.

25 Iuste iudex es una pieza a 3 voces de textura básicamente homofónica y silábica. Únicamente el cantus está lleva texto, las otras voces llevan las rúbricas tenor y contra[tenor]. Llama la atención su abundante sonoridad de terceras así como algunos paralelismos de quintas en falsa relación, rasgos recuerdan al Ave maris stella de Apt (f. 15v).

26 El Credo del folio 177r-v, que fue originalmente copiado sin minimae por un escriba al que Gómez denomina $\alpha$, es una versión mensurada (canto fratto) del Credo I del Graduale Romanum. La intervención de $\beta$ consiste en la adición de algunas minimae, fundamentalmente para ornamentar giros carenciales.

27 Este Gloria es una pieza sumamente refinada y compleja. Se divide en tres secciones, cada una de las cuales concluye con un extenso pasaje isorrítmico. El tejido contrapuntístico se caracteriza por un contratenor muy activo, lleno de saltos, que cruza constantemente al tenor. Palabras como "Chiste" y "Jesu" aparecen iluminadas con fermatas sobre acordes de quinta+tercera. Únicamente el cantus lleva texto. Transcrito por Hanna HARDER en Corpus Mensurabilis Musicae. [Roma], American Institute of Musicology, 1962, vol. 29 Fourteenth-Century Mass Music in France, p. 54 y M ${ }^{\mathrm{a}}$ Carmen Gómez MunTaNé en Polyphonic Music of the Fourteenth Century. Monaco, Editions de l'Oiseau Lyre, 1992, vol. 23A French Sacred Music (PMFC XxIIIA), pp. 168-171. 
TABLA 1. COMPARACIÓN CALIGRAFÍA MUSICAL DE LOS ESCRIBAS $\beta$ Y $\delta$

\begin{tabular}{|c|c|c|c|}
\hline & $\begin{array}{c}\text { Credo } \\
\text { f. } 178 \mathrm{r}-\mathrm{v}\end{array}$ & $\begin{array}{c}\text { Iuste iudex } \\
\text { f. 196v }\end{array}$ & $\begin{array}{c}\text { Gloria } \\
\text { ff. 198v-199r }\end{array}$ \\
\hline $\begin{array}{c}\text { Minimae } \\
\text { negras }\end{array}$ & & & \\
\hline $\begin{array}{c}\text { Signum } \\
\text { congruentiae }\end{array}$ & & & \\
\hline
\end{tabular}
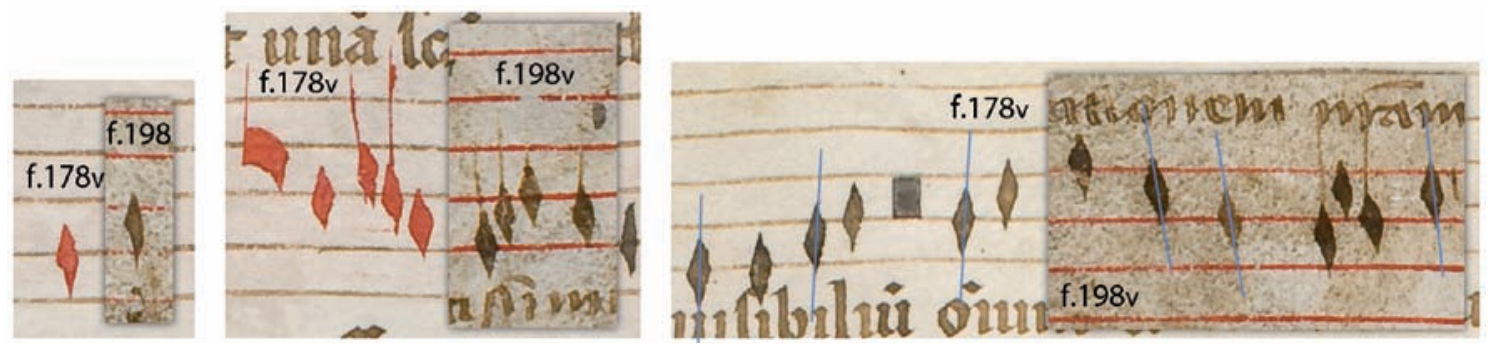
Sobre este Gloria cabe además mencionar otro detalle que hasta el momento no había sido notado. En el centro superior del folio 198v, donde empieza el cantus del Gloria, figura la inscripción "petrus". Se trata de la atribución a su compositor: un cierto Petrus, de quien por ahora nada sabemos. Un examen con radiación ultravioleta ${ }^{28}$ me ha permitido reconocer caracteres de la inscripción apenas legibles a simple vista y observar un fino ornamento afiligranado que introduce el nombre "petrus". ${ }^{29}$

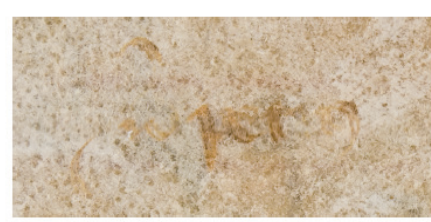

f. 198v - Atribución "petrus"

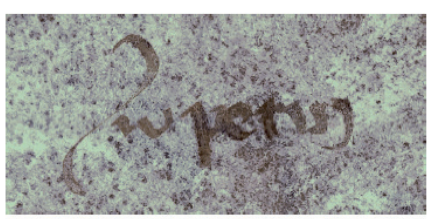

Restauración digital.

Figura 7. Atribución "Petrus” del Gloria Polifónico (f. 198v-199r)

El corpus principal del códice recibió igualmente una innumerable cantidad de correcciones, modificación de melodías, anotaciones marginales, etc. Vale la pena detener la mirada en algunas de estas intervenciones, ya que existen varios casos que de nuevo nos acercan al entorno del escriba $\beta$.

El copista principal (A) dejó tres Alleluya incompletos en los ff. 150v-151r y 152r, de los cuales únicamente copió el texto dejando los pentagramas sin música. ${ }^{30}$ Una mano posterior, del siglo XIV, añadió música en esos espacios vacíos. El ductus firme y cuadrado de su notación musical, así como los custodes, bemoles, la clave de fa, etc., hacen pensar una vez más en alguien muy cercano a $\beta$, alguien que comparte sus mismas características caligráficas musicales.

La tinta negra de estas intervenciones es claramente distinta a la empleada en el Credo (f.178), Iuste iudex y el Gloria de Petrus, de tono más marrón. También el tamaño de las notas es ligeramente menor con respecto a la caligrafía musical de $\beta$. No obstante, una pequeña corrección efectuada por $\beta$ sobre el texto de uno de estos Alleluya (f. 151r) confirma la conexión entre la actividad de ambos individuos. ${ }^{31}$

28 El examen fue realizado el día 15 de septiembre 2009 en el Laboratorio de Restauración y Conservación de la Biblioteca Nacional de España (BNE). Agradezco la muy amable colaboración de Ernesto Capdevielle (BNE), Amelia Justo (BNE) y Carmen Julia Gutiérrez (Universidad Complutense de Madrid).

29 Me pregunto si ese "ornamento' podría ser una $m$ de magister o el anagrama de algún compositor.

30 Una rúbrica en el margen de $152 \mathrm{r}$ reza "vacat".

31 La mano de $\beta$ se reconoce tanto por su caligrafía libraria (pluma, ductus, tamaño) como por su tinta (marrón).

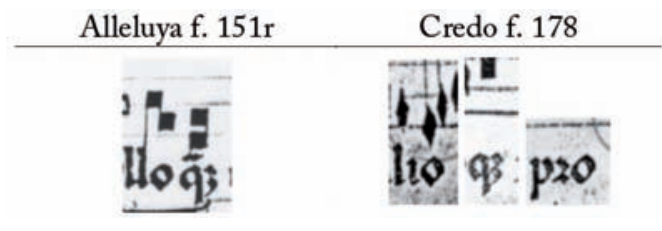


La corrección consiste en un cambio de disposición del texto para adaptarlo a la nueva música. El escriba que añadió música al Alleluya (al que llamo $m$ ) se tomó la molestia de raspar un segmento del texto de A para modificar la posición de un par de sílabas. La mano $\beta$, por su parte, añade otras dos sílabas que m olvidó en el proceso. Otra mano posterior (s. Xv?) introduce modificaciones melódicas en notación blanca con una tinta marrón más clara.

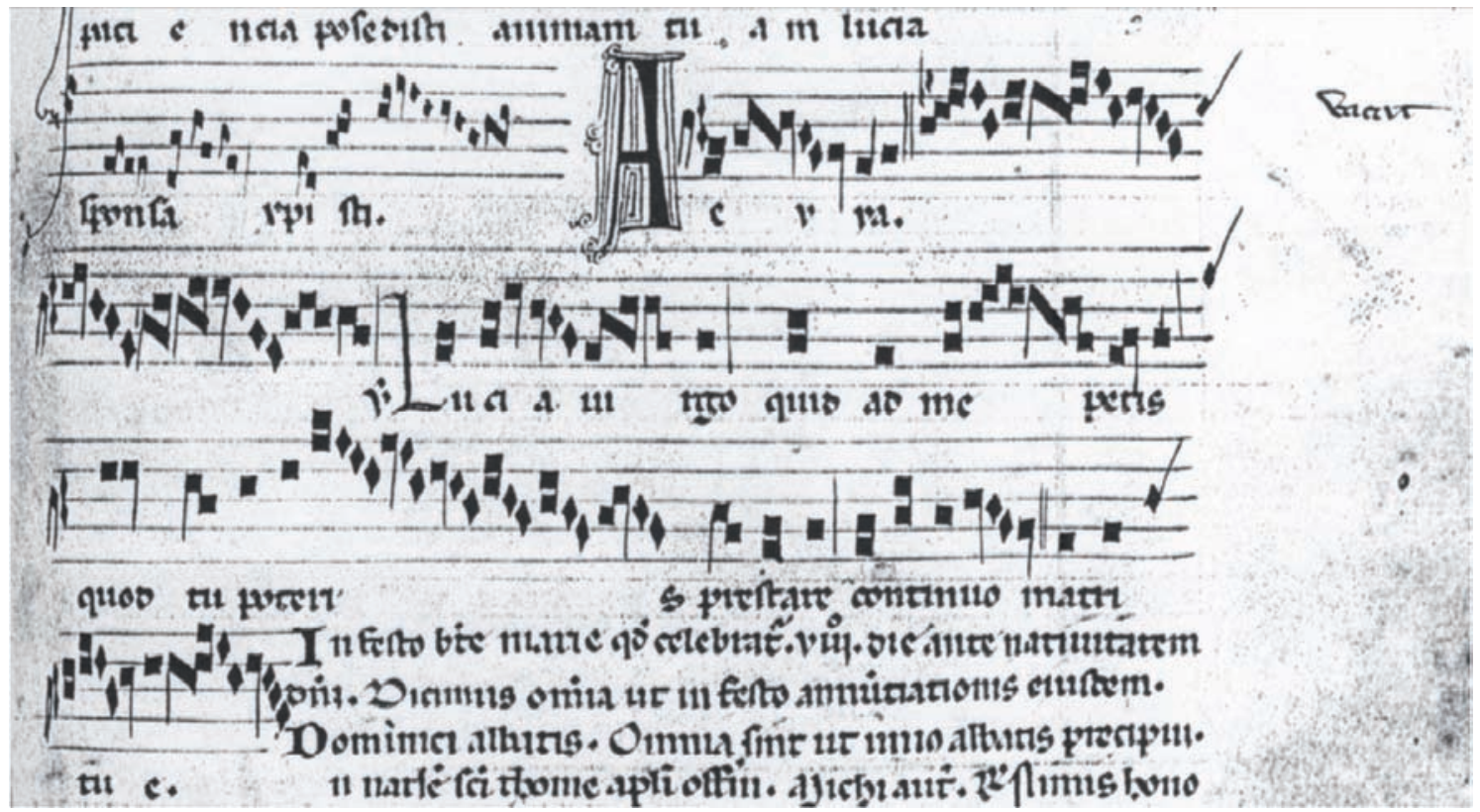

Figura 8. M1361 f. 152r - ALLELUYA

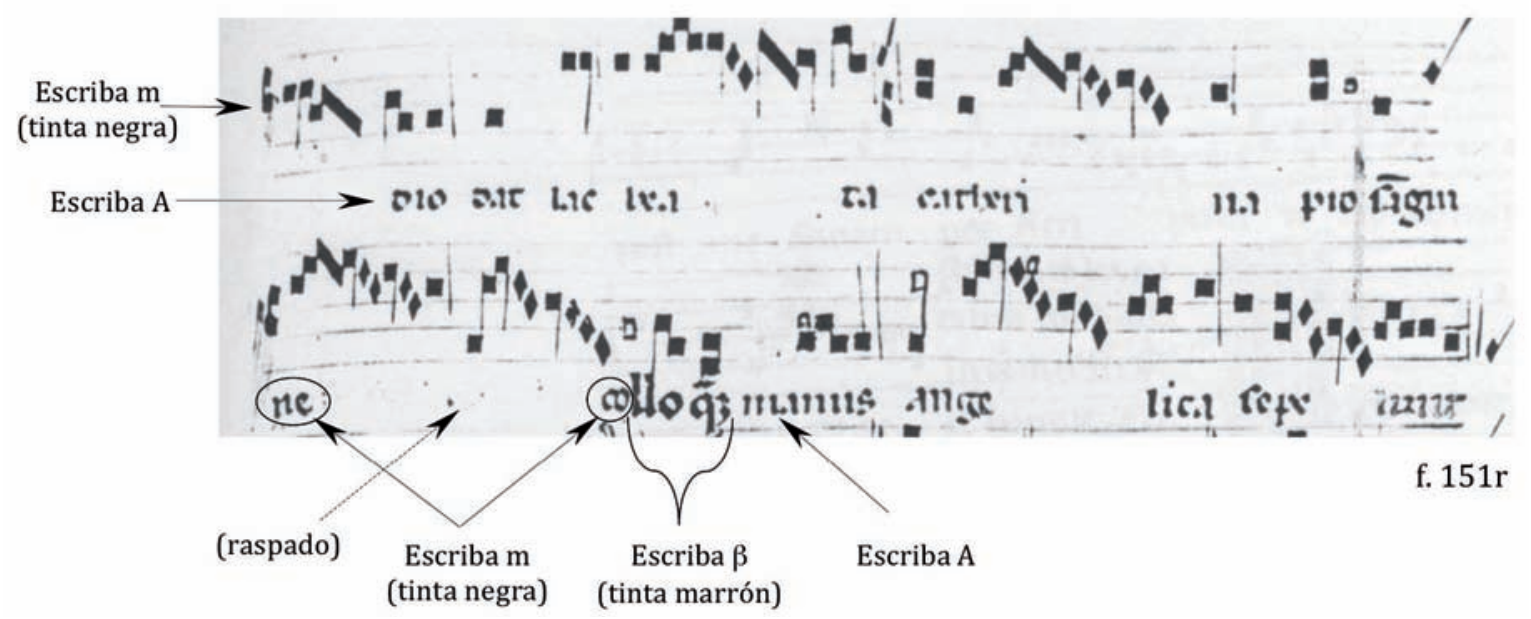

Figura 9. M1361 f. 151r - Intervención de $\beta$ sobre el texto 
En conclusión, todo este tejido de relaciones caligráficas sugiere un entorno musical fuertemente cohesionado, un grupo de personas pertenecientes a la misma escuela. La actividad de $\beta$ se encuentra ligada a la de este grupo de escribas. El hecho de que $\beta$ y su grupo se perfilen además como 'usuarios' del corpus principal del códice litúrgico es un dato de sumo interés.

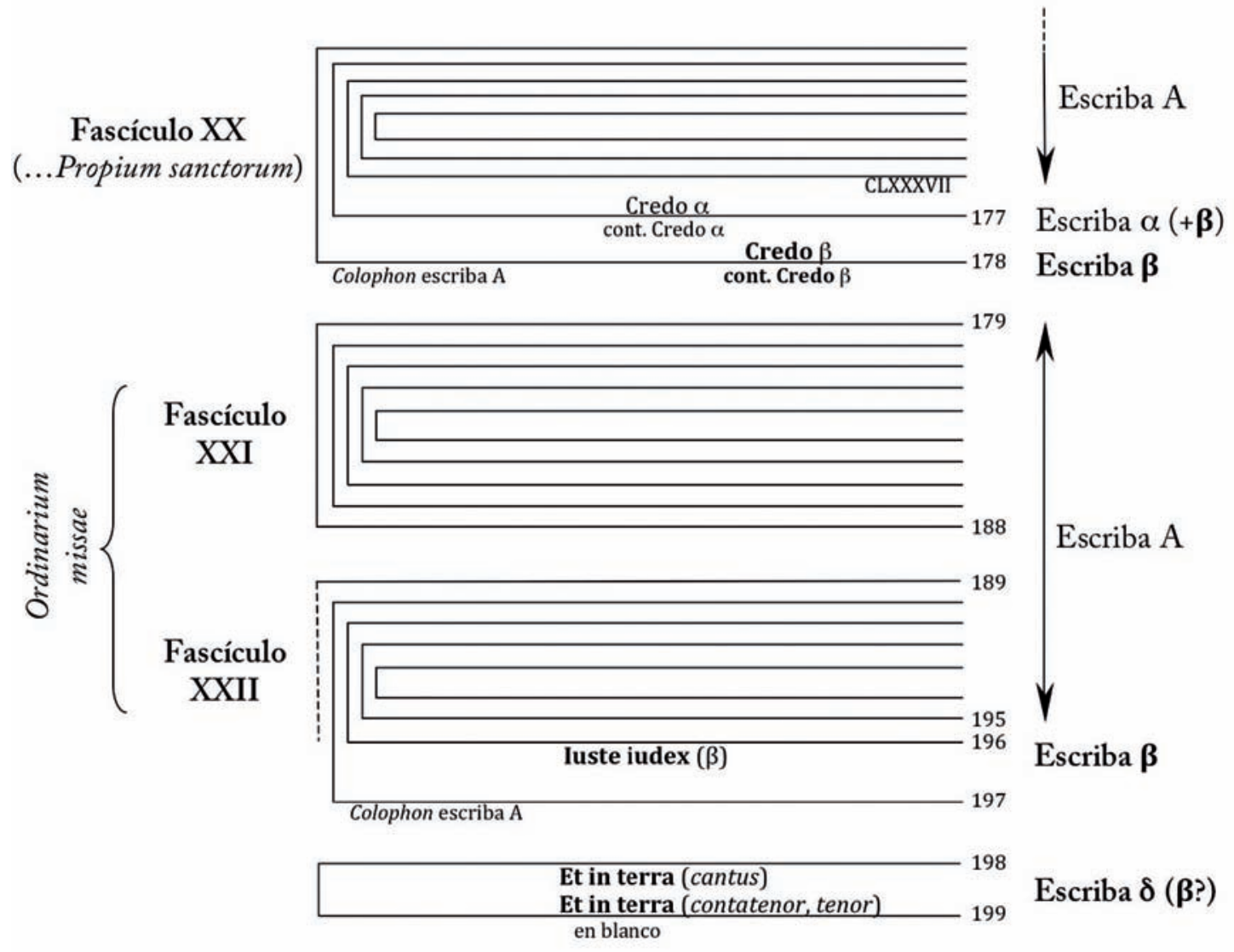

Figura 10. Esquema codicológico de los últimos fascículos de M1361

\section{SOBRE EL ORIGEN Y PROCEDENCIA DE M1361}

Sobre la procedencia de M1361 nada cierto se sabe aparte de su entrada a la Biblioteca Nacional como parte del Fondo Barbieri (olim G-2a -31). ${ }^{32}$ Higinio Anglés pensaba que pudo haber sido copiado en Catalu-

32 La nota de registro de la Biblioteca Nacional no aporta ninguna otra información. El códice aparece inventariado también en el Índice de la biblioteca de Barbieri (Madrid, Biblioteca nacional de España, MS 20461) bajo la signatura G-2a-31, pp. $102 \mathrm{v}-103 \mathrm{r}$, pero el único dato que Barbieri proporciona es el precio que pagó por comprarlo: "5 pesetas". No especifica el lugar 
ña. ${ }^{33}$ En 1991 Maricarmen Gómez situaba la historia antigua del manuscrito en algún lugar "impossible de déterminer, mais située très probablement dans le Royaume de Castille". ${ }^{34}$ Según Gómez, "Contrairement à l'opinion d'Anglés (...), il semble évident qu'un manuscrit dont le titre d'une des aditions musicales est en castillan, 'La noche', et qui porte le nom d'un certain Petrus de Arevalus, sûrement responsable de quelques unes de ces additions, aurait circulé en Castille à l'époque ou celles-ci ont été faites." ${ }^{35}$ No obstante, en 1969 José Janini ya se había referido a este manuscrito como "Gradual de Toledo". ${ }^{36}$ Según Janini, "El santoral y la fiesta de la dedicación de la iglesia, el día 25 de octubre (f. 149, en el margen, de mano posterior) denotan claramente la iglesia de Toledo." Tanto Anglés como Janini llamaron la atención sobre el detalle de que muchos ofertorios llevan la rúbrica "Offrenda" en lugar de Offertorium.

Efectivamente, entre los santos hispanos del Gradual, muchos son los nombres provenientes o relacionados con Toledo: San Ildefonso, Santa Leocadia, San Eugenio, San Vicente, Santa Sabina, Santa Cristeta, etc. Pero además existen muchos otros indicios que vinculan a M1361 con la diócesis toledana. Según Juan Carlos Asensio, la lista alleluiática del M1361 coincide con la de la iglesia de Toledo. ${ }^{37}$ En el plano de la las concordancias y la filiación de lecturas y variantes, Arturo Tello ha demostrado recientemente que el repertorio de tropos de $\mathbf{M 1 3 6 1}$ (contenido en los dos últimos fascículos, ordinarium missae) mantiene relaciones muy estrechas con otros manuscritos de Toledo. ${ }^{38}$ Tello expone toda una serie de argumentos filológicos e históricos que le hacen pensar en la abadía de San Vicente de la Sierra y su scriptorium como posible origen del manuscrito, sin perder de vista la abadía de Santa Leocadia extramuros. En adición, resulta muy significativo que en el folio 149r se añada la "dedicatio ecclesie" justo al lado de Vicente, Sabina y Cristeta, los tres hermanos mártires talaveranos, santos patrones de la abadía de San Vicente de la Sierra. ${ }^{39}$

La abadía de San Vicente de la Sierra, situada a unos 40 kilómetros de Toledo, tuvo una notable vitalidad en el siglo XII y la primera mitad del XIII, siendo uno de los centros escriptorios más activos de

\footnotetext{
donde lo compró ni quién se lo vendió. Aunque la investigación sigue en curso, por el momento no he podido encontrar ninguna otra referencia en el fondo de "Papeles Barbieri" que aporte alguna pista acerca de dónde pudo adquirirlo.

33 Anglés, Higini: Catálogo Musical de la Biblioteca Nacional de Madrid. Barcelona, Instituto Español de MusicologíaCSIC, 1946-51 (p. 99). Anglés no explica con claridad el motivo que le hace pensar en un origen catalán.

34 Gómez Muntané, Maricarmen: op. cit. 1991, p. 248 [aquí cito la versión de 1992 en L’Ars nova italiana del Trecento VI, p. 196].

35 Gómez Muntané, Maricarmen: op. cit. 1991, p. 255 [aquí cito la versión de 1992 en L’Ars nova italiana del Trecento VI, p. 199].

36 JaninI, José: Manuscritos litúrgicos de la Biblioteca Nacional. Madrid, Dirección General de Archivos y Bibliotecas, 1969, p. 284.

37 Juan Carlos Asensio, comunicación personal en enero del 2010. Sobre la variabilidad de las listas alleluiáticas en función de las tradiciones locales véase Huglo, Michel: "Les listes alléluiatiques dans les témoins du graduel grégorien" en Speculum Musicae artis, Festschrift Henrich Husmann, Munich, 1970, pp. 219-227.

38 Tello, Arturo: "De Toulouse a Toledo. Un ejemplo de transmisión cultural del canto a través de los tropos del ordinario", comunicación en el congreso Transitions. 18th Congress of the International Musicological Society, Zürich, 10-15 julio 2007; Tello, Arturo: Transferencias culturales en la Europa de la Edad Media: Los tropos del ordinarium missae en los manuscritos españoles. Madrid, Universidad Complutense, 2006 (Tesis Doctoral).

39 San Vicente de la Sierra era una abadía regida por la Regla de San Agustín y las Consuetudines de San Rufo. Sobre la historia de esta abadía véase CALvo, A.: "La abadía de San Vicente de la Sierra (Toledo). Aportación documental para su estudio histórico", I Congreso de Historia de Castilla-La Mancha, 1988, vol. 5, pp. 237-247; y RuBIo, J. P.: Las Órdenes religiosas y la introducción del Rito Romano en la Iglesia de Toledo. Una aportación desde las fuentes litúrgicas. Toledo, Instituto Teológico de San Ildefonso, 2004.
} 
la diócesis. ${ }^{40}$ A mediados del siglo XIII la abadía comenzó a caer en declive hasta que a finales de siglo la vida regular se hizo insostenible. Algo similar sucedió con Santa Leocadia extramuros. A principios del siglo XIV ambas abadías, San Vicente y Santa Leocadia, fueron secularizadas y convertidas en colegiatas con una estructura clerical muy similar a la del propio cabildo catedralicio, lo que significó su definitiva vinculación a la Catedral de Toledo.

Este último capítulo sucedió más o menos en la época en que M1361 debió ser copiado, lo que lleva a preguntarme si la interrupción de la miniatura tuvo algo que ver con esos tiempos de crisis. Me pregunto igualmente si la adición de los dos últimos fascículos pudiera ser síntoma de un cambio de función del manuscrito relacionado con estos hechos; o incluso si alguna de las anotaciones marginales litúrgicas o alguna de las modificaciones melódicas (para adaptarlas a nuevos ritos) ${ }^{41}$ podrían sugerir un cambio de emplazamiento del manuscrito, desde alguna de estas abadías hacia la Catedral de Toledo. En cualquier caso, el esplendor polifónico reflejado en sus folios residuales parece más propio de una catedral que de un monasterio en decadencia.

A pesar de que la relación de M1361 con la iglesia de Toledo está totalmente demostrada, muchas preguntas acerca de su origen preciso y su historia primitiva quedan aún completamente abiertas. Para aproximarse a una respuesta más o menos definitiva será necesario realizar un nuevo estudio profundo y sistemático sobre los aspectos litúrgicos de M1361 y, en especial, sobre la enorme cantidad de anotaciones marginales. Así mismo, queda pendiente un análisis filológico del repertorio contenido en los primeros veinte fascículos.

Por último, sabiendo que Petrus de Arévalo es el nombre del copista principal de M1361, ésta parece también una buena pista a seguir en futuras investigaciones en los archivos de la Catedral de Toledo, donde se guarda la mayor parte de la documentación procedente de los monasterios pertenecientes a la diócesis toledana.

\section{EL CREDO DEL FOLIO 178, UN PROCESO EDITORIAL CREATIVO}

La diversidad de géneros y estilos musicales relacionados con $\beta$ y su entorno hace pensar en un centro musical considerablemente activo. Pero la experiencia musical de $\beta$ sobrepasa con creces a la de un simple copista. Un análisis minucioso de sus procedimientos escriturarios revela que $\beta$ realizó sustanciales modificaciones durante la 'copia' del Credo que hoy vemos en el folio 178. Por esta razón, antes de formular cualquier hipótesis acerca del fragmento subtilior debemos primero contextualizarlo dentro de un proceso mixto entre copia y 'transformación'.

40 Curiosamente, uno de los casos más antiguos de reclamos verticales conocidos es un breviario elaborado en San Vicente de la Sierra, hoy conservado en Toledo, Bibl. Capitular MS 33-5. Rodríuez, E.: op. cit. 1999, p. 13.

41 El caso de Exultet (ff. 82v-83r) podría aportar pistas al respecto. Su melodía original fue borrada y sustituida por la de una nueva práctica. Véase Nelson, K.: "Commemoration of the Light: the Exultet in Toledo Sources from c. 1200 to c. 1600 " en Musicological Studies, 2006, vol. LXxxIv, pp. 71-87. 
El Credo del folio 178 tiene tres correspondencias conocidas en Ivrea, Cividale y Mallorca. ${ }^{42}$ Estas tres versiones, al margen de pequeñas variantes entre sí, presentan en común un modesto y constante ductus rítmico de breves y semibreves. ${ }^{43}$ Sin embargo, la versión de M1361 exhibe extensos pasajes ricamente ornamentados, con abundantes minimae (grupos de hasta 6 consecutivas) y figuraciones rítmicas muy variadas: ritmos yámbicos, troqueos, hemiolas, etc., para lo cual el escriba $\beta$ recurrió frecuentemente a la coloración (roja) y la evacuación (figurae vacue). Estos pasajes ornamentales se concentran únicamente en determinadas secciones correspondientes a algunos versos del Credo, el resto de versos conserva rigurosamente el austero ductus de Ivrea o Cividale. Curiosamente, las secciones ‘simples' y 'ornamentadas' aparecen dispuestas en alternatim.

\section{TABLA 2. ESTRUCTURA CREDO f. 178}

Verso
Patrem (entonación)
Factorem caeli
Et in unum Dominum
Et ex patre natum
Genitum, non factum
Qui propter nos
Crucifixus
Et resurexit
Et iterum
Et in Spiritum
Qui cum Patre
Et unam sanctam
Confiteor
Et expecto
Amen

Estilo
Simple
Simple
Ornam.
Simple
Ornam.
Simple
Ornam.
Simple
Ornam.
Simple
Ornam.
Simple
Ornam.
Simple
Polifónico

\section{Notación}

Negra. Sin minimae.

Negra. Sin minimae.

Negra, roja y blanca. Con minimae.

Negra. Sin minimae.

Blanca y roja (sólo 3 notas negras al principio). Con minimae.

Negra. Sin minimae.

Blanca y roja. Con minimae.

Negra. Sin minimae.

Blanca y roja. Con minimae.

Negra. Sin minimae.

Blanca y roja. Con minimae.

Negra. Sin minimae.

Blanca y roja. Con minimae.

Negra. Sin minimae.

Negra. Sin minimae. / Discantus: signos proporcionales (3 \& 4) y mensural (๔), minimae y semiminimae.

Algunos detalles en la alineación música-texto, así como la elección de ciertos recursos de notación rítmica, inducen a pensar que el escriba $\beta$ tomó parte activa en la introducción de todas estas variantes. El texto se presenta regularmente agrupado por palabras, de lo que se deduce que fue enteramente copiado en una primera fase antes de anotar la música. ${ }^{44}$ Puesto que la música fue cuidadosamente alineada con respecto al texto, su densidad gráfica (espacio entre las notas) quedó totalmente subordinada a la disposición del texto. Por esta razón, la densidad gráfica de la música se vuelve en ocasiones muy irregular.

42 Ivrea, Biblioteca Capitolare 115, f. 64v; Cividale, Museo Arqueologico Nazionale 79, f. 1v+4r; Palma de Mallorca, Archivo de la Catedral MS s/n, f. 54v-55v (Cantoral del Convento de la Concepción).

43 La versión de Mallorca incluye algunas minimae aisladas, sobre todo en fórmulas cadenciales, en el estilo de la intervención del escriba $\beta$ en el Credo de $\alpha$ (M1361 f. 177r-v). El Amen de Cividale termina en Sol, el de Mallorca en Re, mientras que el de M1361 termina en Mi. Cabe señalar que el Credo copiado por la mano $\alpha$ en el folio anterior (M1361 f. 177v) tiene el mismo Amen que el Credo de $\beta$; la misma melodía y el mismo final en Mi, sin embargo la penúltima nota (Re) es longa (como veremos más adelante, este detalle rítmico es de gran relevancia). El Amen de M1361 con la finalis en Mi parece pues una variante local, una fórmula recurrente en el entorno donde M1361 fue usado.

44 Que no es otro escriba quien copia el texto se deduce porque: (1) la tinta es idéntica en el texto y en la música; (2) Iuste iudex tiene la misma caligrafía textual y musical que el Credo f. 178 (incluyendo las rubricas "tenor" y "contra[tenor]"). 
No obstante, durante la copia del texto, algunas palabras, como "ce-lis", "se-culi" o "A-men", fueron interrumpidas para dejar espacio a pequeños melismas. Paradójicamente, estas palabras pertenecen a secciones simples. En cambio, la falta de espacio en las secciones ornamentadas (p.ej. palabras como "unigenitum", "pecatorum" o "pilato") provocó una densidad límite en la notación musical. El escriba se vio forzado entonces a comprimir drásticamente el cuerpo de las notas. Todo esto sugiere que las ornamentaciones no figuraban en el antígrafo empleado por $\beta$. De lo contrario, hubiese previsto el espacio necesario para tan vistosos melismas. Obviamente, sólo previó el espacio de los melismas que veía en su antígrafo mientras copiaba el texto. ${ }^{45}$

\section{TABLA 3. DENSIDAD GRÁFICA}
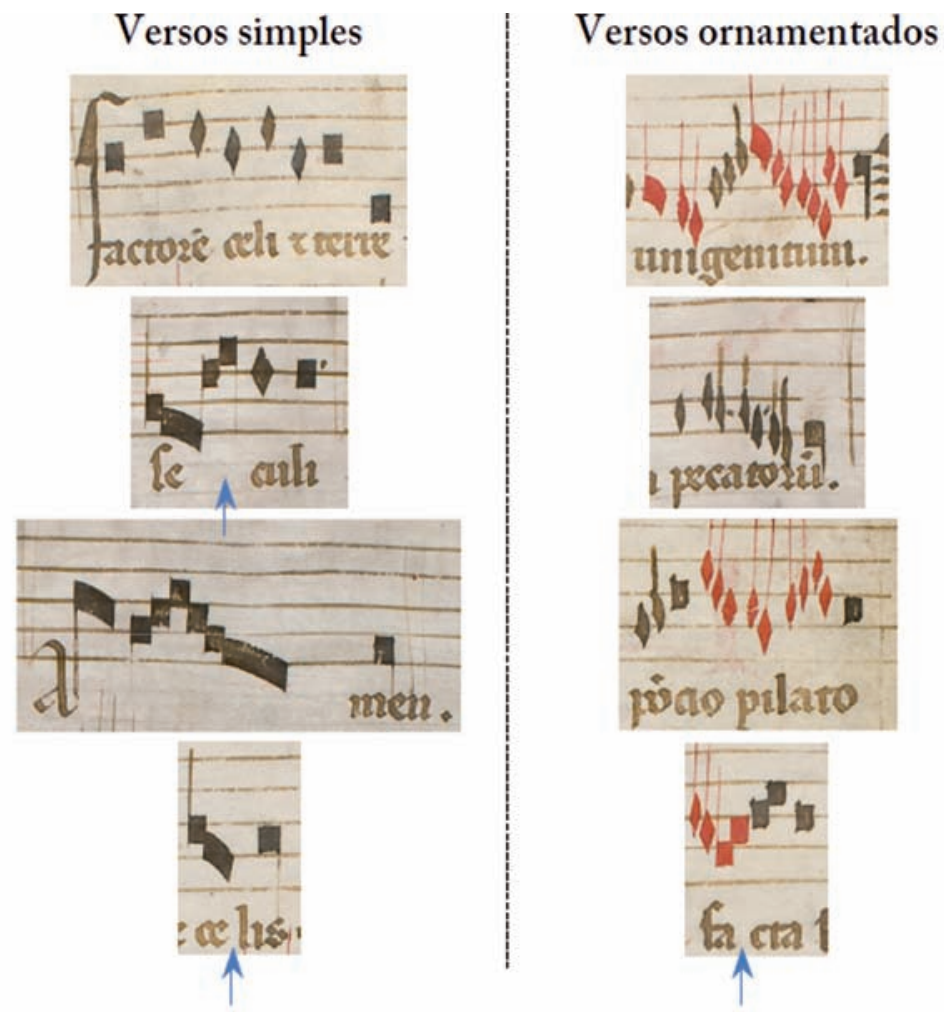

45 La única palabra interrumpida que aparece dentro de una sección ornamentada es "fa-cta". Sin embargo el motivo de su interrupción no fue dejar espacio a nuevo material musical, puesto que su entonación es una simple ligadura de dos notas entonación que no debió distar mucho a la versión de su antígrafo-. En cambio, $\beta$ no previó espacio para ninguna de las vistosas disminuciones repletas de minimae. La disposición textual del entero Credo es muy característica de una musicalización silábica con apenas algún que otro micro-melisma aislado; se comporta exactamente igual en las secciones simples como en las ornamentadas. El hecho de que todas las palabras interrumpidas coincidan con micro-melismas también presentes en las otras versiones del Credo (Mallorca, Ivrea y Cividale) es un detalle del todo significativo. 
Aparte de la densidad gráfica, las secciones ornamentadas (que están en prolación mayor) se distinguen de las simples por su notación blanca (notas vacue) y un uso abundante de coloración roja (la coloración se usa aquí para indicar imperfección). Teniendo en cuenta que las secciones simples no contienen minimae, y por tanto puede decirse que "no tienen" prolación, la función de la notación blanca pudo haber sido: (1) señalar algún tipo de relación proporcional entre las secciones simples y ornamentadas; ${ }^{46}$ o bien, (2) enfatizar la idea de alternancia distinguiendo visualmente las secciones ornamentadas de las simples. ${ }^{47}$ Cabe mencionar que para ello el escriba $\beta$ se tomo la molestia de utilizar tres plumas distintas; una para cada tipo de notación. ${ }^{48}$ Sea como fuere, el código notacional resulta claro y transparente: notación negra para las secciones simples; notación blanca y roja para las secciones ornamentadas.

Ahora bien, la cristalina coherencia de este sistema notacional aparece al principio de la pieza un tanto confusa, mientras que a partir de la tercera sección ornamentada se vuelve rigurosamente sistemática. La primera sección ornamentada, Et in unum Dominum, empieza con una combinación de notación negra y roja, pero hacia final de la sección sustituye la notación negra por notación blanca. La siguiente sección ornamentada, Genitum non factum, inicia con un grupo de notas negras seguido de una hemiola roja, y a partir de ese momento solo combina notación blanca y roja. El resto de secciones ornamentadas vienen anotadas exclusivamente en notación blanca y roja.

Se observa aquí a un escriba en acción de experimentar con diversas posibilidades de notación; probando, cambiando de opinión, decidiendo sobre la marcha qué tipo de notación le resulta más conveniente para su propósito. Una vez establecido el sistema, lo utiliza metódicamente.

\section{EL AMEN DEL CREDO, UNA AMPLIFICACIÓN POLIFÓNICA SUBTILIOR}

Maricarmen Gómez Muntané señaló en su artículo de 1991 que el Credo monódico del folio 178 viene seguido por un "petit fragment vocal ou instrumental, dans tout cas sans texte, qui utilise

46 Desconocemos qué significación específica pudo haber tenido la notación blanca en referencia a una posible relación proporcional.

47 Siguiendo esta línea, me pregunto si la diferenciación visual pudo estar relacionada con la intención de comunicar algún tipo de información sobre la performance del alternatim, por ejemplo una alternancia entre cantores.

48 Usar plumas diferentes para la notación negra y roja es del todo habitual; con ello se evita que las tintas se mezclen. La tercera pluma, la usada para la notación evacuada, se reconoce fácilmente por su grosor. Esta es la misma pluma que $\beta$ usó para añadir minimae al Credo de $\beta$. La tinta aparece muchas veces corrida en el interior del cuerpo de las notas. En ocasiones la única manera de distinguir la notación blanca es por el grosor de las caudas.

\section{Credo f. 178}

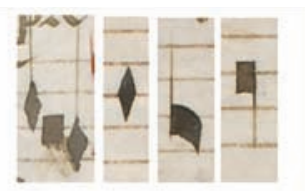

negra

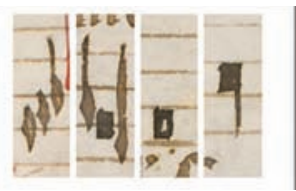

blanca

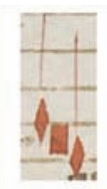

roja
Intervención de $\beta$ en el Credo de $\alpha$

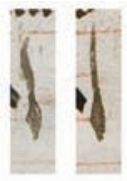

Credo f. $177 \mathrm{v}, \alpha+\beta$

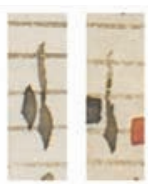

Credo f. $178 \mathrm{r}, \beta$ 
des signes de mensure ( $3 \& \subset$ )", sin aportar ningún otro comentario al respecto. ${ }^{49}$ En 1993, Karl Kügle se refería brevemente a este Credo para indicar que el pequeño "fragmento sin texto" era en realidad una segunda voz añadida al Amen del Credo, convirtiéndolo por tanto en polifónico. ${ }^{50}$ Pero, en 1998, Gómez aprovechó la ocasión de un artículo sobre el Cantoral del Convento de la Concepción de Mallorca para contestar duramente a Kügle, insistiendo en que no existe ningún indicio que permita relacionar polifónicamente el fragmento sin texto con el Amen del Credo. ${ }^{51}$ Estas fueron sus alegaciones:

“Karl Kügle (...) apoya su hipótesis con una transcripción en la que corrige por tres veces el fragmento sin explicar el motivo, lo cual no deja de sorprender puesto que el resto de la pieza carece de errores. La primera corrección la aplica al pasaje de doce mínimas en proporción cuádruple que sigue a otro en proporción triple respecto al fragmento inicial, que va en tiempo imperfecto en prolación menor. En proporción triple tres mínimas equivalen a una mínima del tiempo inicial, y por tanto son doce, en lugar de cuatro, las que equivalen a una breve del tiempo imperfecto con prolación menor. En su transcripción Kügle hace equivaler doce mínimas en proporción cuádruple a una breve en tiempo imperfecto con prolación menor, con lo cual las interpreta en proporción triple y no en cuádruple.

La segunda corrección consiste en reducir a la mitad el valor de la longa y la semibreve que preceden a la última longa. A continuación supone que el pasaje equivalente a dos breves y una longa en tiempo imperfecto con prolación mayor con el que concluye el fragmento sin texto equivale al de dos breves y una longa en tiempo imperfecto con prolación menor con el que concluye el Amen, es decir que ambos pasajes guardan la proporción $3 / 2$.

Con las correcciones señaladas, a las que se suma la supresión del Sib de la armadura para evitar el tritono final, el Amen funciona polifónicamente, sin ellas hay que suponer que es monódico y que tras él sigue un breve fragmento vocal o tal vez instrumental a una voz, relacionado o no con el Patrem que le precede." 52

49 En 1962 Hanna Harder ya se había referido a este fragmento "with apparently no connection with the Amen". HARDER, H.: Fourteenth-Century Mass Music in France, American Institute of Musicology, Musicological Studies and Documents, 1962, vol. 7 , p. 170 .

50 KÜGLE, K.: "A fresh look at the liturgical settings in manuscript Ivrea, Biblioteca Capitolare 115" en Revista de Musicología, 1993, vol. Xvi/4, pp. 2458-2459.

51 Gómez Muntané, Maricarmen: "Una fuente desatendida con repertorio sacro mensural de fines del medioevo: el cantoral del convento de la Concepción de Palma de Mallorca" en Revista Aragonesa de Musicología, 1998, vol. xIv/2, pp. 333-372. En su libro La música medieval en España (Kassel 2001) Gómez Muntané insiste de nuevo en su idea de que el fragmento sin texto es monódico, señalando que al Credo de M1361 "le fue añadida una prolongación en Ars subtilior al melisma del Amen." (p. 251, la enfatización en letra cursiva es mia).

52 Gómez Muntané, Maricarmen: op. cit. 1998, p. 354. 


\section{EJEMPLO 1. COMPARACIÓN DE LAS INTERPRETACIONES DE GÓMEZ Y KÜGLE}
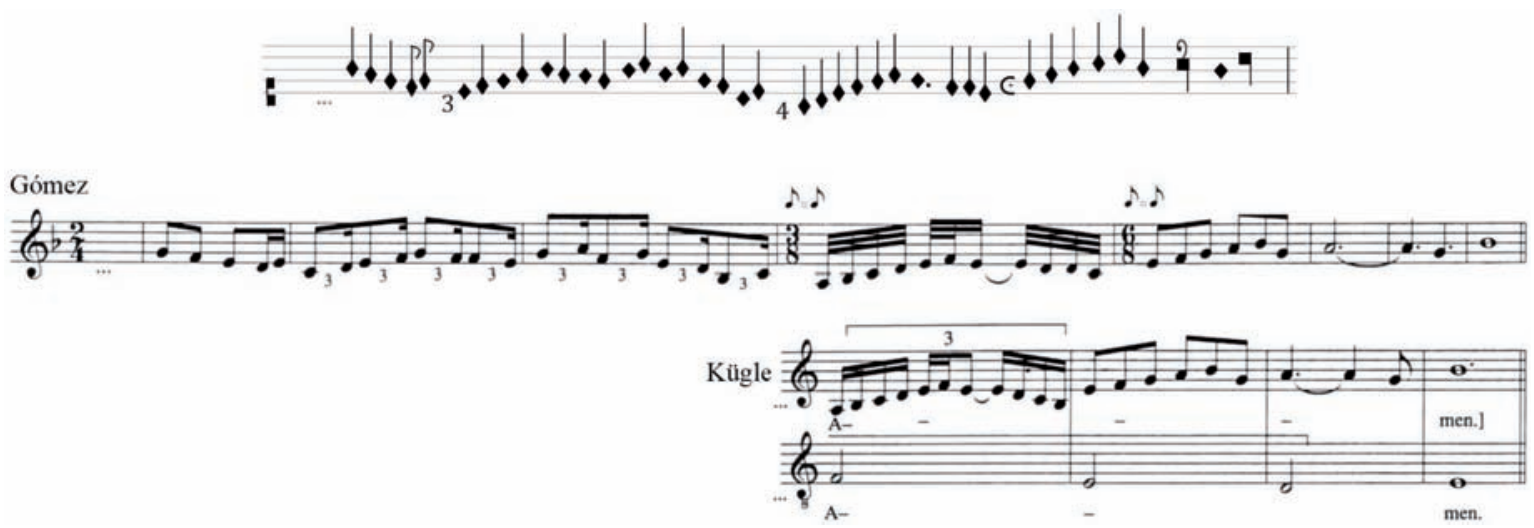

Según Gómez, Kügle realiza las siguientes enmiendas en su transcripción:

(1)- interpreta el signo '4' como proporción triple y no cuadruple.

(2)- hace coincidir el valor de la breve en $\subset$ y $\odot$, con lo que interpreta $\odot$ en proporción $3 / 2 .{ }^{53}$

(3)- reduce a la mitad el valor de la longa y la semibreve que preceden a la nota final.

(4)- suprime el Si bemol de la armadura para evitar un tritono.

Los argumentos que Gómez expone para rebatir la hipótesis de Kügle merecen ser aquí detalladamente matizados.

En primer lugar, el fragmento sin texto no lleva ningún "Sib" en la clave (véase Figura 2).

En segundo lugar, la disminución 4:1 que Gómez propone es ciertamente infrecuente en el repertorio tardomedieval en tanto que proporción entre figuras iguales. Generalmente para expresarla no se usa signos proporcionales, sino cambios de figura, como semiminimae, fusae o dragmae. En Torino, Biblioteca Nazionale, s. J.II.9 (Codex Chipre), puede encontrarse esta rara proporción 4:1, expresada con el signo $\odot{ }^{54}$ y en menos ocasiones con el número ' 4 ' ${ }^{55}$ En esta fuente el significado más frecuente de ' 4 ' es 4:3, ${ }^{56}$ pero puede llegar a significar proporciones tan extravagantes como 5:2. ${ }^{57}$ Mod A y Chantilly, en cambio, muestran un uso mucho más consistente del signo ' 4 '. En estas dos fuentes se observa que, en contexto de prolación mayor, '4' significa siempre proporción dupla ${ }^{58}$ mientras que en prolación menor significa proporción

53 Según la teoría arsnovista francesa, una breve en $\odot$ es dos minimae más grande que en $\subset$. En consecuencia, al hacerlas coincidir Kügle estaría interpretando $\subset$ en proporción sesquialtera con respecto a $\subset$.

54 Por ejemplo: Se de mon mal delivre prestement (To ff. 124v-125).

55 Je prens d'amour noriture (To f. 154r).

56 Por ejemplo: Se de mon mal (To ff. 124v-125r); Celle en qui j'ai mise m'amour (To f. 131r); Sur toute fleur la rose est colourie (To f. 137r); etc.

57 Por ejemplo: Puis que ame sui doulcement (To f. 107r).

58 Por ejemplo: Medee fu (Ch f. 24v), "Canon: ad figuram 3 in preporcione sesquialtera; ad binaria in preporcione sesquitercia; ad quaternariam in proporcione dupla; (...)”. Otro ejemplo: L'orques Arthus (Ch f. 40). 
TRIPLA. ${ }^{59}$ Consecuentemente, en el caso de nuestro fragmento sin texto, la interpretación de ' 4 ' como una mutatio qualitatis de la proporción 3:1 expresada anteriormente por el signo '3' (organizándola ahora en 3 grupos de cuatro en lugar de 4 grupos de tres minimae) no debería parecer una idea tan descabellada.

En tercer lugar cabe recordar que, en el terreno del Ars subtilior, los signos mensurales $(\subset, \odot$, etc.) pueden adquirir significado proporcional, ${ }^{60} \mathrm{o}$ que el signo ' 3 ' representa proporciones tan diversas como 3:1, 3:2 o 9:6. ${ }^{61}$ Así pues, a falta de un canon explicativo, la deducción del significado de los signos proporcionales y mensurales depende inevitablemente del contexto en el que aparecen. Y esto incluye tomar en consideración aspectos de análisis musical, estructura contrapuntística, melódica, etc.

Teniendo en cuenta todo esto, las cuatro "correcciones" que Gómez imputa a Kügle podrían fácilmente reducirse a una sola: la reducción de las dos penúltimas figuras. La cuestión consiste entonces en determinar si dicha descoordinación mensural es argumento suficiente para desvincular ambas voces, o si, por el contrario, caben otras hipótesis alternativas al respecto. Para dilucidar esta cuestión propongo reiniciar de nuevo todo el argumento partiendo de dos preguntas fundamentales:

(1) ¿Cuál es la naturaleza de este enigmático fragmento sin texto?; y

(2) ¿Cuáles son exactamente los indicios que conducen a suponer su relación con el Amen?

(1) Ambitus, figuración melódica, rítmica... nuestro misterioso fragmento tiene claramente todo el aspecto de una línea de discantus. Esencialmente, está compuesto en base a una combinación de diversos segmentos de 5, 6 y 8 notas ascendentes o descendentes. Al final de cada pasaje-escala hay siempre un pequeño cambio de dirección que actúa de nexo entre los pasajes. En términos ciconianos ${ }^{62}$ podría hablarse de una colección de species agregatae, ya sean intensae o remisae, a las que se anexa una silaba final en dirección opuesta. La combinación de todos estos elementos configura un florido mosaico plagado de detalles sutiles.

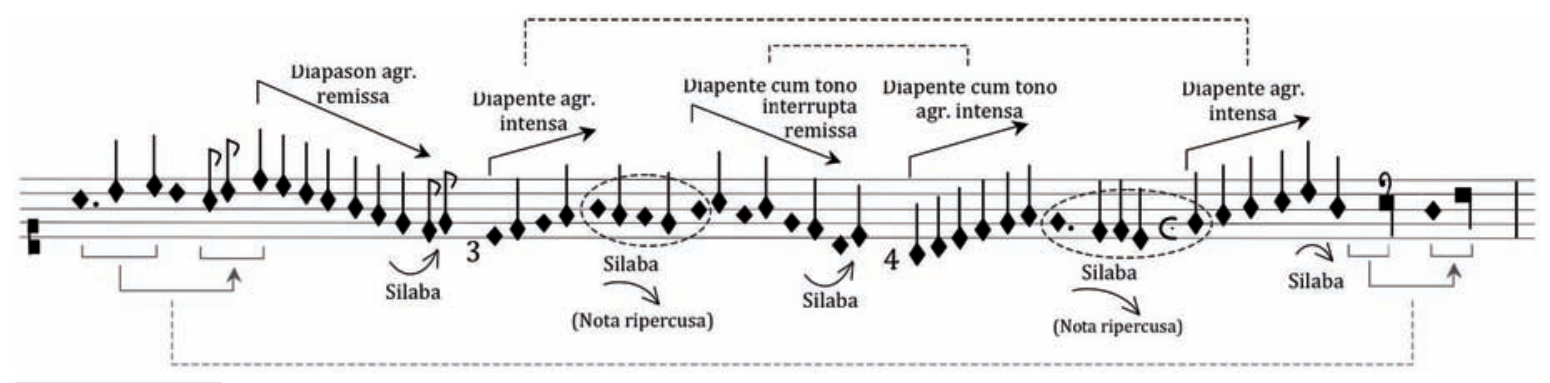

59 Por ejemplo: Ma douce amour de Hasprois (Mod f. 28r), "Canon: ad figuram ternariam [signo '3'] in proporcione sexquialtera cantetur, ad binariam [in proporcione] dupla, ad QUATERNARIAM vero [in proporcione] TRIPLA cantetur” (!). Es decir: '2' = 2:1; '3'= 3:2; '4' = 3:1.

60 Por ejemplo: en Une dame requis de Johannes de Jauna (Mod f. 12r, mensura de base: $\subset$ ) la breve es siempre constante aún cuando los signos de mensura cambian $(\odot, \odot$ y $\bigcirc)$.

61 En Angelorum psallat de Rodericus, (Ch f. 48v) el signo ‘3' significa proporción 3:2; en Se doulz espoir de Corradus de Pistoia (Mod f. 31v) significa 3:1; en Belle, bonne, sage de Cordier (Ch f. 11v) significa 9:6.

62 Johannes Ciconia: Nova Musica. Editado por Oliver B. Ellsworth, University of Nebraska Press, 1993. El argumento de este tratado expone paralelismos entre el arte de la música y la gramática, la retórica, la dialéctica o la lógica, estableciendo una serie de parámetros según los cuales una melodía puede ser analizada. La terminología empleada es la siguiente: specie = intervalos mayores o iguales a una cuarta; silaba = intervalos menores que una cuarta; agregata = intervalo "relleno" a modo de escala; disgregata: intervalo "vacío" a modo de salto; interrupta = specie "rellena" solamente de algunos grados; intensa = intervalo ascendente; remissa $=$ intervalo descendente. 
Entre las silabae colocadas al final de cada specie, dos de ellas llaman la atención por contener una repetición de notas. Después de cada par de notas repetidas, la nota inmediatamente posterior desciende una segunda y la siguiente a ésta asciende una tercera. En el lenguaje contrapuntístico del Ars nova este tipo de giros son muy característicos de las clausulae (movimientos cadenciales), y por tanto sugieren un cambio de nota en el tenor. Ahora bien, ¿qué tenor?

(2) Para analizar mejor la hipótesis de Kügle, según la cual el fragmento sin texto es un contrapunto del Amen, usaremos una transcripción diplomática en la que el Amen, desprovisto de ritmo, ha sido alineado con el discantus de la manera contrapuntísticamente más plausible. Es decir, observando los indicios melódicos que sugieren cadencias o pasos contrapuntísticos y conjeturando posibilidades de contrapunto en los pasajes menos obvios.

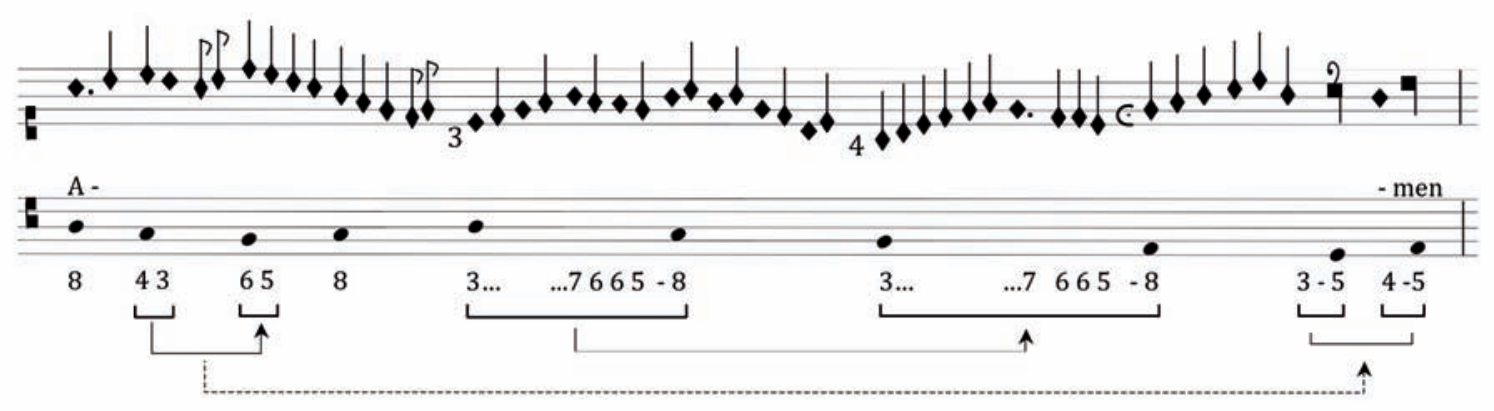

Las siguientes observaciones generales destacan a primera vista:

- La hipotética construcción polifónica no presenta una estructura contrapuntística especialmente disonante.

- El inicio de cada pasaje-escala coincide sistemáticamente con un cambio de nota en el Amen.

- La alineación del primer segmento hasta la aparición del signo '3' coincide inequívocamente con el ritmo mensural del Amen.

- La primera silaba cadencial coincide con una clausula 6(5)-8, de lo que se deduce la interpretación del signo '3' como proporción tripla.

- La segunda silaba cadencial coincide con otra clausula 6(5)-8, de lo que se deduce la interpretación del signo '4' como mutatio qualitatis de la proporción tripla.

- La silaba que conecta la escala de cinco minimae con la longa La coincide con una pequeña clausula 3-5, de lo que se deduce el significado proporcional de $\odot$.

- La longa La sobre la que resuelve esta pequeña clausula viene además señalada con un signum congruentiae, que elimina cualquier ambigüedad acerca del signo $\odot$ y orienta a visualizar la cadencia final. 
Una mirada más atenta desvela muchos otros detalles de interés. Sobre la $2^{\mathrm{a}}$ nota del tenor se observa una apoyatura 4-3 y sobre la $3^{\mathrm{a}}$ una apoyatura de 6-5, con la que inicia el primer pasaje-escala descendente. Así pues, el tránsito entre la $2^{\mathrm{a}}$ y $3^{\mathrm{a}}$ nota del tenor viene a ser en realidad una pequeña clausula 3-5 ornamentada con apoyaturas tanto en su 'paenultima' como en su 'finalis'. La primera de las apoyaturas va precedida de una minima que configura una silaba agregata de tercera, mientras que la segunda va precedida de una anacrusa en semiminimae que configura una specie de cuarta interrupta. La dialéctica de estas dos apoyaturas y sus respectivas anacrusas es del todo elocuente, puesto que crea una intensificación del discurso musical a nivel contrapuntístico, melódico y rítmico. ${ }^{63}$

\section{Dialéctica de apoyaturas y anacrusas}

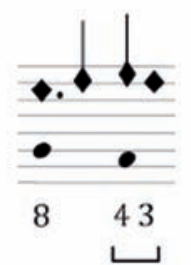

anacrusa: silaba agregata apoyatura: 43

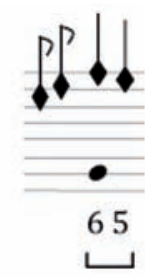

anacrusa: specie interrupta apoyatura: 65

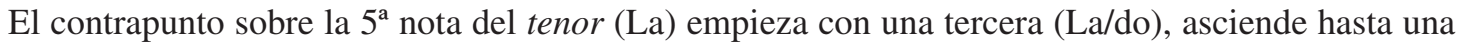
séptima (La/sol), y finalmente desciende con un "giro cadencial" (nota repetida) para resolver en contrapunto de octava sobre la siguiente nota del tenor. Teniendo en cuenta la primera y últimas notas del contrapunctus diminutum, la estructura contrapuntística entre las $5^{\mathrm{a}}$ y $6^{\mathrm{a}}$ notas del tenor podría describirse así:

$$
\begin{array}{ccc}
3 \ldots & \ldots 7665-8 \\
\mathrm{La} & - & \text { Sol }
\end{array}
$$

El contrapunto sobre la $6^{\mathrm{a}}$ nota del tenor $(\mathrm{Fa})$ parte igualmente de una tercera $(\mathrm{Fa} / \mathrm{la})$. El contrapunctus diminutum asciende esta vez hasta alcanzar la octava (Fa/fa). Luego desciende para reposar brevemente sobre una séptima $(\mathrm{Fa} / \mathrm{mi})$ y continúa descendiendo con otro giro cadencial. Es decir, de nuevo el mismo esquema descrito para el tránsito entre $5^{\mathrm{a}}$ y $6^{\mathrm{a}}$.

$$
\begin{aligned}
& \text { 3... ..7665-8 } \\
& \mathrm{Fa} \quad \text { - Mi }
\end{aligned}
$$

63 A nivel de contrapunto, el intervalo sobre el que resuelve cada apoyatura es cada vez mayor. Desde el punto de vista melódico, las anacrusas van ampliando el ámbito de cada inflexión. Al mismo tiempo, su textura rítmica acelera. 
Obviamente se trata de la misma estructura contrapuntística dibujada con figuraciones rítmicas y melódicas distintas. Es interesante notar que de estas dos clausulae, una sea auténtica (o cerrada) y otra plagal (o abierta; con el semitono en la voz inferior).

El fragmento concluye con un paralelismo de quintas, cuya sonoridad más bien "arcaica" contrasta con la elegancia de un incipit tan refinado, como si diferentes registros estilísticos entraran en juego. También aquí es interesante el juego entre las silabae precedentes a cada quinta. Si melódicamente contrapone una segunda a una tercera, contrapuntísticamente confronta una tercera a una cuarta.

$$
\begin{array}{cccc}
8 \ldots & \ldots 3-5 & 4-5 \\
M i & - & R e & - \\
\end{array}
$$

El principio y el final del Amen se asemejan por el diálogo entre su figuras anacrúsicas, y en cambio se diferencian por la presencia o ausencia de apoyaturas.

\section{Movimientos cadenciales}

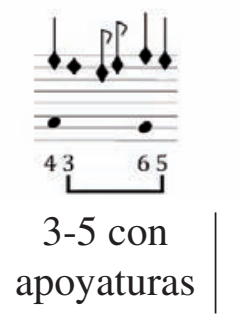

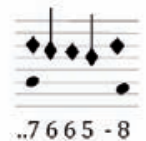

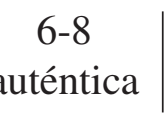

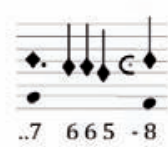

6-8 plagal

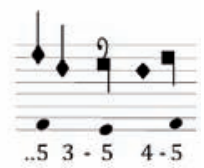

$3-5$ y $4-5$

Una última observación concierne a la superficie rítmica implícita en la interpretación propuesta para el discanto. Su paso a través de las diversas proporciones responde a una "flexibilidad agógica" cier-

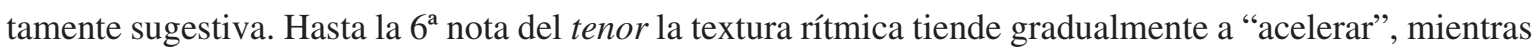
que a partir de la $8^{\text {a }}$ mensura se percibe un notable "decelerando". Torino J.II.9 transmite los ejemplos más extremos de este tipo de agógicas flexibles, donde extensos pasajes de contrapunto diminuido aceleran y deceleran con una fluidez extraordinaria. ${ }^{64}$

El examen de esta hipotética sincronización polifónica conduce a pensar que la relación entre el Amen y el fragmento sin texto puede ser todo menos casual. El análisis revela un discurso melódico y contrapuntístico sutil, trazado con inteligencia, bien equilibrado y coherente estéticamente con estilos polifónicos contemporáneos. La elocuente dialéctica de apoyaturas y anacrusas, clausulae, estructuras simétricas, pequeños elementos contrastantes, etc., demuestra una sensibilidad musical altamente refinada. Sea cual sea el motivo que explique la descoordinación mensural entre estas dos voces, queda suficientemente demostrado que no se trata de dos melodías superpuestas al azar.

64 Je prens d'amour noriture (To f. 154r) es uno de los ejemplos más conocidos. 
Según el patrón de alternatim, el Amen debería ser la última sección ornamentada. Pero, en lugar de ornamentación melódica, la amplificación polifónica actúa como una especie de clímax conclusivo. La idea del Amen polifónico parece por tanto haber sido un elemento importante dentro de la nueva arquitectura musical concebida por el escriba.

Dicho todo esto, el dilema de la descoordinación podría resolverse de varias maneras. Un modo sería privilegiar el ritmo del tenor y enmendar la mensuración del discantus, tal como hizo Kügle. Pero, el proceso de sustituir una breve y una minima por una longa y una semibreve es una operación compleja (difficilior), y por tanto menos plausible como ‘error de copia'; más bien parece tratarse de una 'elección'. Modificar el ritmo del tenor, sería en realidad la solución más económica. Para ello, sería suficiente con modificar la forma de la última nota de esa ligatura y hacerla terminar en cuadrada, en lugar de oblicua, o simplemente añadir una cauda descendente al final de la ligadura.

La explicación más sencilla de este fenómeno tal vez se encuentre de nuevo en la interferencia entre procesos de copia y composición. Es decir: si el escriba hubiera compuesto él mismo este discantus después de haber copiado el Amen tal y como lo veía en su antígrafo, durante el proceso de composición pudo haberse replanteado la 'agógica' de la cadencia final, alargando el valor de la paenultima a modo de 'ritardando' ${ }^{65}$ Entonces, o bien olvidó volver atrás para 'corregir' el tenor, o bien no consideró necesario hacerlo. ${ }^{66}$

\section{5. ¿SUBTILITAS EN LA PRÁCTICA DEL BISCANTO IMPROVISADO?}

El análisis del proceso escriturario de este Credo proporciona valiosísimas informaciones acerca de las habilidades musicales y creativas de su escriba. Como ha podido comprobarse en los anteriores apartados, existen varios indicios que sugieren fuertemente el rol activo del escriba en la introducción de variantes durante el proceso de copia. La falta de espacio para las disminuciones ornamentales, la gradual sistematización del código notacional, la pequeña descoordinación mensural del Amen ... vistos en su conjunto, todos estos detalles, que no son más que accidentes de 'imprevisión' -y que no pueden explicarse dentro de un proceso mecánico de copia-, podrían responder a una misma explicación común, a un mismo síntoma. La autoría de $\beta$ toma fuerza entonces como la hipótesis más simple y sugerente.

65 No es tan extraño que la construcción de un nuevo discurso contrapuntístico sobre un tenor prius factus pueda revertir en pequeñas modificaciones del propio tenor. Este caso recuerda al de otro pequeño fragmento en el manuscrito Siena, Biblioteca Comunale degli Intronati, L.V.36, recientemente estudiado por Pedro Memelsdorff. Se trata de un contrapunto sobre el Kyrie IV ("Cunctipotens Genitor Deus") que, según Memelsdorff, parece el ejercicio de un "fruitore" del material pedagógico contenido en el manuscrito. Un pequeño raspado en el tenor delata un "ripensamento" rítmico en relación a la "intentio contrapuncti" elegida por el escriba. Memelsdorff, Pedro.: "Siena 36 rivisata. Paolo da Firenze, Johannes Ciconia, e l'interrelazione di polifonia e trattatistica in fonti del primo Quattrocento" en Acta Musicologica, 2004, vol. 76, pp. 159-91.

66 Tratándose de un breve fragmento de apenas una línea, resulta verosímil que un lector experimentado fuese capaz de visualizar a golpe de ojo la alineación contrapuntística del discantus con respecto a su tenor. El signum congruentiae debió bastar para eliminar cualquier ambigüedad al respecto. Cabe recordar que el Credo copiado por la mano $\alpha$ en el folio anterior (M1361 $\mathrm{f}$. $177 \mathrm{v})$ tiene el mismo Amen que el Credo de $\beta$ con su penúltima nota (Re) longa; los cantores del entorno de M1361 debieron estar acostumbrados a esa formula. 
No obstante, la constatación de algunos puntos paradójicos invita a continuar reflexionando sobre el orden de los procesos mentales llevados a cabo por el escriba. Por un lado, una estructura alternatim tan perfectamente calibrada sólo puede explicarse desde su previa planificación. Pero, por otro lado, los accidentes de imprevisión sugieren al mismo tiempo cierto grado de espontaneidad, es decir, decisiones tomadas durante el acto de escritura. La pregunta resulta entonces inevitable: ¿cuál era el 'proyecto originario’ de $\beta$ ?, ¿de qué modo y en qué momento se generó (o se fue generando) la nueva versión de este Credo en la mente del escriba?

La primera respuesta posible es evidente: el plan original de 'copia' se vio modificado después de haber introducido el texto. En el momento de inscribir la música, $\beta$ decidió crear una nueva estructura basada en la alternancia de secciones ornamentadas. Presuponemos aquí que si la idea de componer disminuciones ornamentales hubiese figurado en su proyecto original, $\beta$ habría seguido otras estrategias escriturarias (combinando el orden de entrada de texto y música, por ejemplo). Aún así, no deja de sorprender que una transformación tan radical fuese concebida tan espontáneamente en medio del proceso de lo que pretendía ser una simple copia. En el análisis de la tinta no se percibe ningún trauma cronológico entre las fases de escritura de texto y música. ${ }^{67}$

Una segunda hipótesis podría contemplar que el proyecto original de $\beta$ arrancara ya con la conceptualización de una nueva arquitectura musical, pero únicamente desde su abstracción formal, es decir, sin tener en cuenta los detalles internos a la estructura (que fueron compuestos sobre la marcha). El escriba habría adoptado entonces la estrategia de copiar primero el texto por costumbre, por habitus scribendi. Esta posibilidad viene además sugerida por el hecho de que el $\beta$ parece haber previsto de antemano un pentagrama 'extra' para el contrapunto del Amen. ${ }^{68}$

67 Tanto el color del pigmento (con todos sus matices cromáticos) como la constante de decoloración entre carga y carga de tinta de la pluma se mantienen extremadamente similares en texto y música. Todos los detalles que se pueden analizar sugieren que no debió pasar mucho tiempo entre la copia del texto y la inscripción de la música.

$68 \beta$ trazó su pautado de arriba abajo con regla, alternando cinco líneas rojas y dos a punta seca (para el texto). El escriba debió poder calcular con precisión el espacio requerido para el texto en referencia al layout de su antígrafo, que seguramente era parecido a Ivrea (la disposición gráfica de las letras capitales y las secciones es sorprendentemente similar entre M1361 e Ivrea, especialmente el detalle de empezar una nueva sección justo al final del primer pentagrama; parece que $\beta$ haya hecho un gran esfuerzo por conservar rigurosamente la disposición grafica del texto tal y como la veía en su ejemplar).

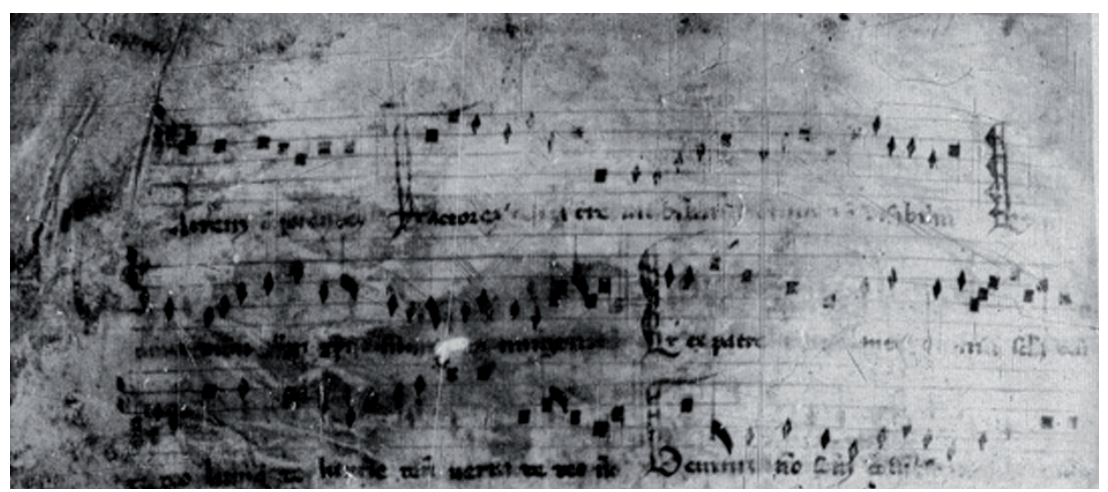

Ivrea, Biblioteca Capitolare 115, f. 64v (principio del Credo). 
En el fondo de la cuestión, todas estas especulaciones desembocan en la misma conclusión: ciertos parámetros estructurales debieron ser calculados a priori, mientras que toda una serie de detalles internos a la estructura fueron concretizados durante el proceso escriturario, como en una especie de improvisación sobre el pergamino. A pesar de tantos imprevistos, el escriba demuestra una gran seguridad y un admirable refinamiento estético. Claramente, esta no debió ser ni su primera ni su única experiencia en contacto con el estilo. Así pues, de la combinación entre su savoir faire y el carácter espontáneo de su trabajo, se deduce una habilidad musical que lo podría capacitar incluso para la improvisación en vivo.

Esta última observación entra en la línea de la teoría esbozada por Anne Stone en 1994, según la cual, al menos uno de recursos notacionales característicos del Ars subtilior (la invención de nuevas figuras $)^{69}$ podría haber sido innovado en un contexto de improvisación musical. ${ }^{70}$ Stone basa su argumento en una aguda comparación entre el estilo y la notación de un determinado grupo de piezas transmitidas en $\operatorname{Mod} \mathbf{A}$, lo que le da pie a reflexionar sobre el rol de la ornamentación en el desarrollo de la notación rítmica a finales del siglo XIv. Bajo esa óptica analiza el caso de En attendant esperance de Senleches (Mod 39v-40r) y la versión de un Credo de Magister Zacharias (Mod 23v-25r) cuya voz superior aparece extraordinariamente ornamentada en comparación con el resto de fuentes concordantes. ${ }^{71}$ Además, Stone respalda su hipótesis citando párrafos de algunos tratados teóricos contemporáneos. En especial destaca una frase extraída del Tractaus figurarum, célebre tratado que describe un enmarañado sistema de figuras inventadas para representar contrapuntos que tienen una mensuración diferente de su tenor. ${ }^{72}$ En el prólogo, el autor anónimo explica la necesidad que le movió a redactar el tratado: "porque sería muy inconveniente que lo que se puede interpretar no se pueda escribir", insinuando que la complejidad rítmica existía previamente a la invención de las nuevas figuras.

Frente a las opiniones de Willi Apel y Ursula Günther -cuyas ideas influyeron decisivamente en la historiografía moderna del Ars subtilior- ${ }^{73}$ la tesis de Anne Stone ofrece un revolucionario punto de vista que desvela la vertiente más espontánea y sensible del Ars subtilior. El testimonio de M1361 apunta en esa misma dirección, pero además añade nuevas perspectivas. En primer lugar, establece una posible

69 Dragmae y composite figurae (figuras del tipo b,,$\delta$, b, etc.).

70 STONE, Anne: Writing rhythm in late medieval Italy: Notation and musical style in the manuscript Modena, Biblioteca Estense, a.M.5.24. Harvard University, 1994 (Tesis Doctoral). Véase también STONE, Anne: "Glimpses of the unwritten tradition in some ars subtilior works" en Musica Disciplina vol. 50, Part of the two volume Essays in Memory of Nino Pirrotta, $1995-1996$ (i.e., 1998), pp. 59-93.

71 Mod A f. 23v-25. Editado en PMFC XIII, pp 118-128. La versión de este Credo de M. Zacharias en Mod A emplea una gran variedad de 'nuevas figuras' para transcribir ornamentos de una fluidez rítmica extraordinaria.

72 Aunque no se conservan fuentes musicales que utilicen figuras exactamente como propone el Tractatus figurarum, sobreviven un total de 14 copias del tratado, lo que apunta al gran interés suscitó entre los músicos de la época.

73 Esta generación de musicólogos transmitieron la imagen de un Ars subtilior rebuscado, cerebral y, en cierto modo, superfluo, rico en artificios técnicos pero pobre en espontaneidad -y por tanto expresividad-. Apel, por ejemplo, afirmaba que en este periodo la notación sobrepasó la función de sirviente de la música para convertirse en una disciplina independiente, un ejercicio puramente intelectual y de especulación matemática. Los juicios de estos musicólogos influyeron de manera decisiva en los manuales de Historia de la Música más populares, como el de Hoppin, Richard: Medieval Music. New York, Norton, 1978. Véase Apel, Willi: The Notation of Polyphonic Music, 900-1600, Cambridge, The Mediaeval Academy of America,1953; Apel, Willi: "The French Secular Music of the Late Fourteenth Century" en Acta Musicologica, 1947, vol. 18, pp. 17-29; GüNTHER, Ursula: "Das Ende der Ars Nova”, en Die Musikforschung, 1963, vol. 16, pp 105-20; GüNTHER, Ursula: “Die Ars subtilior", en Für György Ligeti. Die Referate des Ligeti-Kongresses Hamburg 1988, Laaber, Laaber-Verlag, 1991, pp. 277-88. 
relación entre el estilo subtilior y la práctica del biscanto sobre tenores litúrgicos, género que hasta el momento no había sido considerado dentro del campo de acción de la subtilitas. En segundo lugar sugiere que también el uso de signos proporcionales (y no solamente la invención de nuevas figuras) pudo estar relacionado con el intento de capturar prácticas de improvisación musical. Por último, este pequeño fragmento sin texto, podría sugerir una relación entre la estética subtilior y ciertas prácticas instrumentales que apenas dejaron rastro escrito. ${ }^{74} \mathrm{Si}$ bien existe documentación relativa a los organistas de la Catedral de Toledo desde $1354,{ }^{75}$ nada sabemos acerca de la música que éstos interpretaban, ni mucho menos acerca del rol que órgano pudo jugar en la ejecución de música mensural (polifónica o monódica). El folio 178v del códice M1361 tal vez preserve el único vestigio superviviente de una refinadísima tradición instrumental que, al menos en España, ha quedado -casi- totalmente borrada de la historia de la música.

\section{CONCLUSIÓN}

El códice M1361 de la Biblioteca Nacional de Madrid desvela un centro musical de primer orden en torno a Toledo, donde a finales del siglo XIV debieron escucharse las tendencias musicales más vanguardistas del momento. Uno de los escribas que usaron folios residuales de este códice para anotar piezas de polifonía, reescribió enteras secciones de un Credo mensural y amplificó polifónicamente su Amen en un refinado estilo cercano al Ars subtilior.

La huella creativa de este personaje anónimo aporta pistas muy valiosas relativas a la asimilación del Ars subtilior en la Península Ibérica. M1361, más que transmitir una 'pieza' concreta, tiene el valor de testimoniar una 'práctica', un savoir faire, cuyas ramificaciones debieron ser mucho mayores de lo que vemos en el manuscrito. El análisis de su proceso escriturario permite observar el modus operandi de una mente creativa en acción. Este precioso testimonio invita a continuar investigando sobre la interferencia de las prácticas interpretativas en la transmisión musical manuscrita al final del Medioevo, e instiga a reconsiderar los límites entre interpretación, improvisación, transformación y composición.

La espontánea intervención de este escriba parece un buen pretexto para preguntarse si, además de las cortesanas formes fixes o las grandes ballades encomiásticas, el Ars subtilior pudo tener en tierras hispánicas algún otro tipo de difusión subalterna, como la práctica del biscanto improvisado o una escuela instrumental perdida en el océano del tiempo.

74 Aparte de la ausencia de texto, el tipo de ductus melódico y la excepcional extensión de su ambitus, que alcanza la $8^{\mathbf{a}}+4^{\mathbf{a}}$, me hacen pensar en una parte instrumental, ¿quizás una parte de órgano no intabulada? No da la impresión de que $\beta$ se haya 'olvidado' de añadir texto al discantus, puesto que ya se ha comprobado que este escriba es extremadamente cuidadoso con el tratamiento de texto, según se observa en su intervención sobre el Alleluya del f. 151r y su constante preocupación por mantener una perfecta alineación texto-música en el Credo.

75 Sobre los organistas de Toledo véase GARCía Llovera, Julio Miguel: De organo vetere hispano: zur frühgeschichte der Orgel in Spanien. St. Ottilien, Eos, 1987. 
ANEXO I: Inventario de las adiciones en folios residuales de M1361.

GÓMEZ (2001) identificó diversos escribas secundarios con letras griegas $(\alpha, \beta, \gamma)$. Nuevas identificaciones vienen señaladas con letras minúsculas del alfabeto latino (a, b, c).

\begin{tabular}{|c|c|c|c|c|c|}
\hline Folio & Contenido & Tipo composición & Notación/estilo & Otros comentarios & Escriba \\
\hline \multirow[t]{2}{*}{$1 \mathrm{r}$} & Alleluya. Virga Jesse & Monódico. & Cuadrada blanca. & & $\mathrm{a}$ \\
\hline & $\begin{array}{l}\text { Alleluya. Salue } \\
\text { consurgens }\end{array}$ & Monódico. & Cuadrada blanca. & & $\mathrm{a}$ \\
\hline $177 \mathrm{r}-\mathrm{v}$ & Credo (Patrem) & Monódico mensural. & $\begin{array}{l}\text { Negra }(\sin \text { minimae }) . \\
\text { Escriba } \beta \text { añade } \\
\text { minimae. }\end{array}$ & $\begin{array}{l}\text { Versión libre mensural } \\
\text { (canto fratto) del } \\
\text { Credo I del Graduale } \\
\text { Romanum. } \\
\end{array}$ & $\alpha(+\beta)$ \\
\hline $178 \mathrm{r}-\mathrm{v}$ & Credo & $\begin{array}{l}\text { Monódico mensural, } \\
\text { Amen polifónico ( } 2 \text { v.). }\end{array}$ & $\begin{array}{l}\text { Notación negra } \\
\text { con coloración, } \\
\text { evacuación, minimae. } \\
\text { Amen polifónico } \\
\text { (subtilior): signos } \\
\text { proporcionales, } \\
\text { mensurales, minimae } \\
\text { y semiminimae. } \\
\end{array}$ & $\begin{array}{l}\text { Parafrasea al Credo I } \\
\text { del Gr. Rom. } \\
\text { Correspondencias en: } \\
\text { Ivrea } 115 \text { (f. 64v), } \\
\text { Cividale } 79 \text { (f. 1v+4r) } \\
\text { y Palma de Mallorca } \\
\text { s/n (f. 54v-55v). }\end{array}$ & $\beta$ \\
\hline $178 \mathrm{v}$ & $\begin{array}{l}\text { Kyrie. Ihesu fili } \\
\text { virginis }\end{array}$ & Monódico. & $\begin{array}{l}\text { Cuadrada negra. } \\
\text { Correcciones en } \\
\text { notación blanca. }\end{array}$ & $\begin{array}{l}\text { Al margen: "Kyrie } \\
\text { Sancte Marie Ite }(m ?) \\
\text { secundus tonus novem } \\
\text { lectionum" }\end{array}$ & $\mathrm{b}(+\mathrm{f})$ \\
\hline \multirow[t]{2}{*}{$196 \mathrm{v}$} & $\begin{array}{l}\text { Agnus Dei (3 } \\
\text { entonaciones) }\end{array}$ & Monódico. & Cuadrada negra. & $\begin{array}{l}\text { Título: "La noche". } \\
\text { Utiliza tinta azul. } \\
\text { Al margen, un } \\
\text { colophon encriptado. }\end{array}$ & $\gamma$ \\
\hline & Iuste iudex & Polifónico, 3 voces. & Negra, Ars nova. & $\begin{array}{l}\text { (unicum) Tenor escrito } \\
\text { en tetragrama. } \\
\text { Su textura } \\
\text { contrapuntística } \\
\text { recuerda al Ave maris } \\
\text { stella de Apt (f. } 15 \mathrm{v}) \text {. } \\
\text { Forma: AAB. } \\
\end{array}$ & $\beta$ \\
\hline $197 \mathrm{r}$ & $\begin{array}{l}\text { Fragmento sin texto. } \\
\text { [Contratenor (?)] }\end{array}$ & $\begin{array}{l}\text { [Polifónico] Fragmento } \\
\text { de una sola voz. }\end{array}$ & $\begin{array}{l}\text { Blanca; con minimae, } \\
\text { ligaduras, etc. } \\
\text { Ars nova. }\end{array}$ & $\begin{array}{l}\text { (unicum) Su figuración } \\
\text { recuerda al Ct del } \\
\text { Gloria de Petrus (ff. } \\
\text { 198v-199r) }\end{array}$ & c \\
\hline \multirow[t]{2}{*}{$197 v-198 r$} & Adoramus te Christe & Polifónico, 3 voces. & $\begin{array}{l}\text { Blanca (a la longa) } \\
\text { con arcaísmos } \\
(\text { plicae }) .\end{array}$ & $\begin{array}{l}\text { (unicum) Estilo } \\
\text { híbrido s. XV con } \\
\text { rasgos arcaizantes. }\end{array}$ & d \\
\hline & Alleluya. In ferventis & Monódico. & Cuadrada blanca. & & e \\
\hline \multirow[t]{2}{*}{$197 v$} & Alleluya. Hic est vere & Monódico. & Cuadrada blanca. & & $\mathrm{f}$ \\
\hline & $\begin{array}{l}\text { [Alleluya?...] } \\
\text { (Palimpsesto) }\end{array}$ & Monódico. & Cuadrada blanca. & Palimpsesto. & \\
\hline
\end{tabular}




\begin{tabular}{|l|l|l|l|l|l|}
\hline $198 \mathrm{r}$ & $\begin{array}{l}{[2 \text { melodías }} \\
\text { desconocidas }] \\
\text { (Palimp.) }\end{array}$ & Monódico. & Cuadrada negra. & Palimpsesto. & $\mathrm{g}$ \\
\hline & Alleluya. Anna mater & Monódico. & Cuadrada blanca & & $\mathrm{e}$ \\
\hline $198 \mathrm{v}-199 \mathrm{r}$ & Gloria (Et in terra) & Polifónico, 3 voces. & Negra, Ars nova. & $\begin{array}{l}\text { (unicum). Atribución } \\
\text { "Petrus". }\end{array}$ & $\delta$ \\
\hline
\end{tabular}

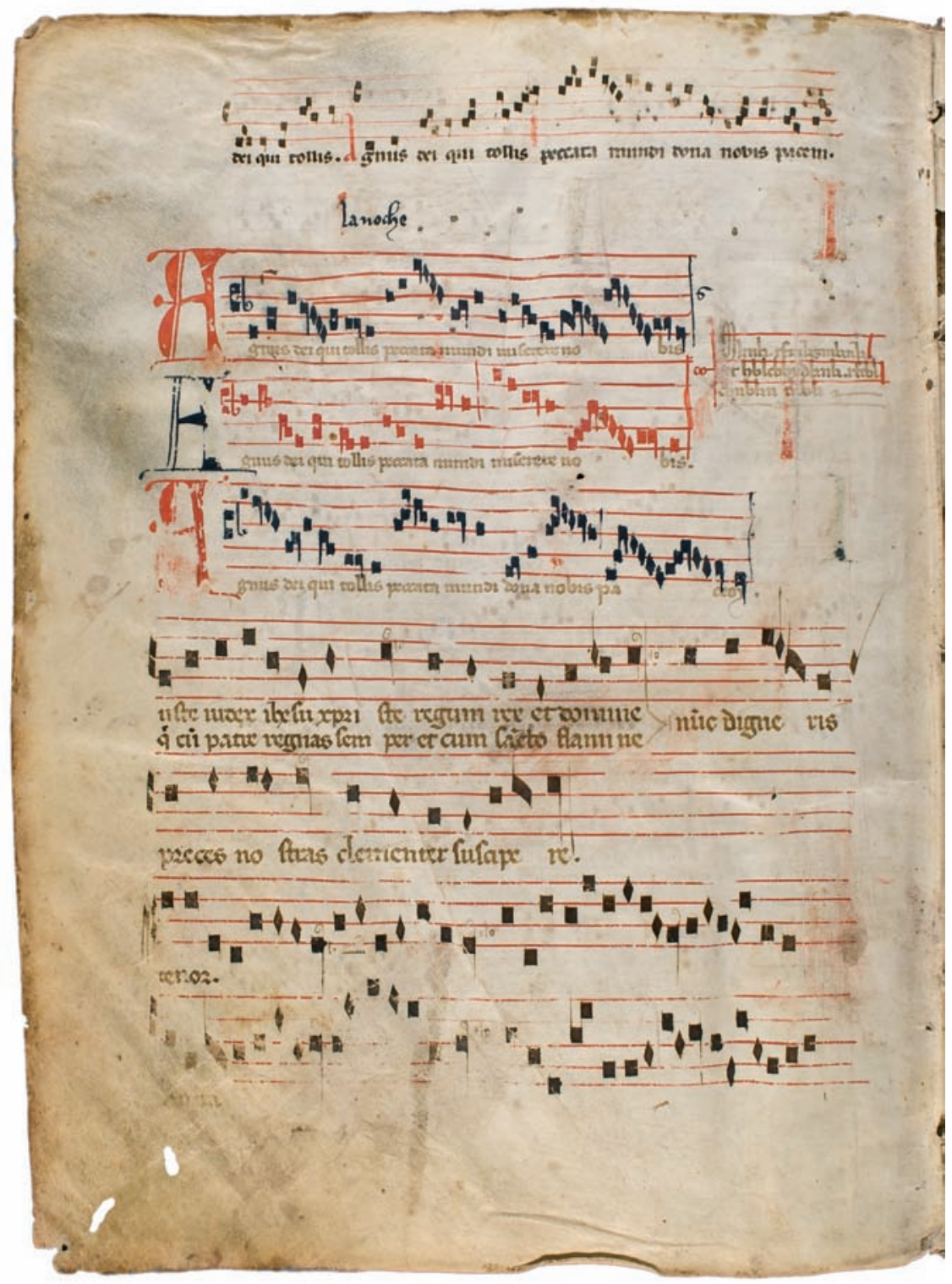

Figura 11. M1361 f. 196v. 


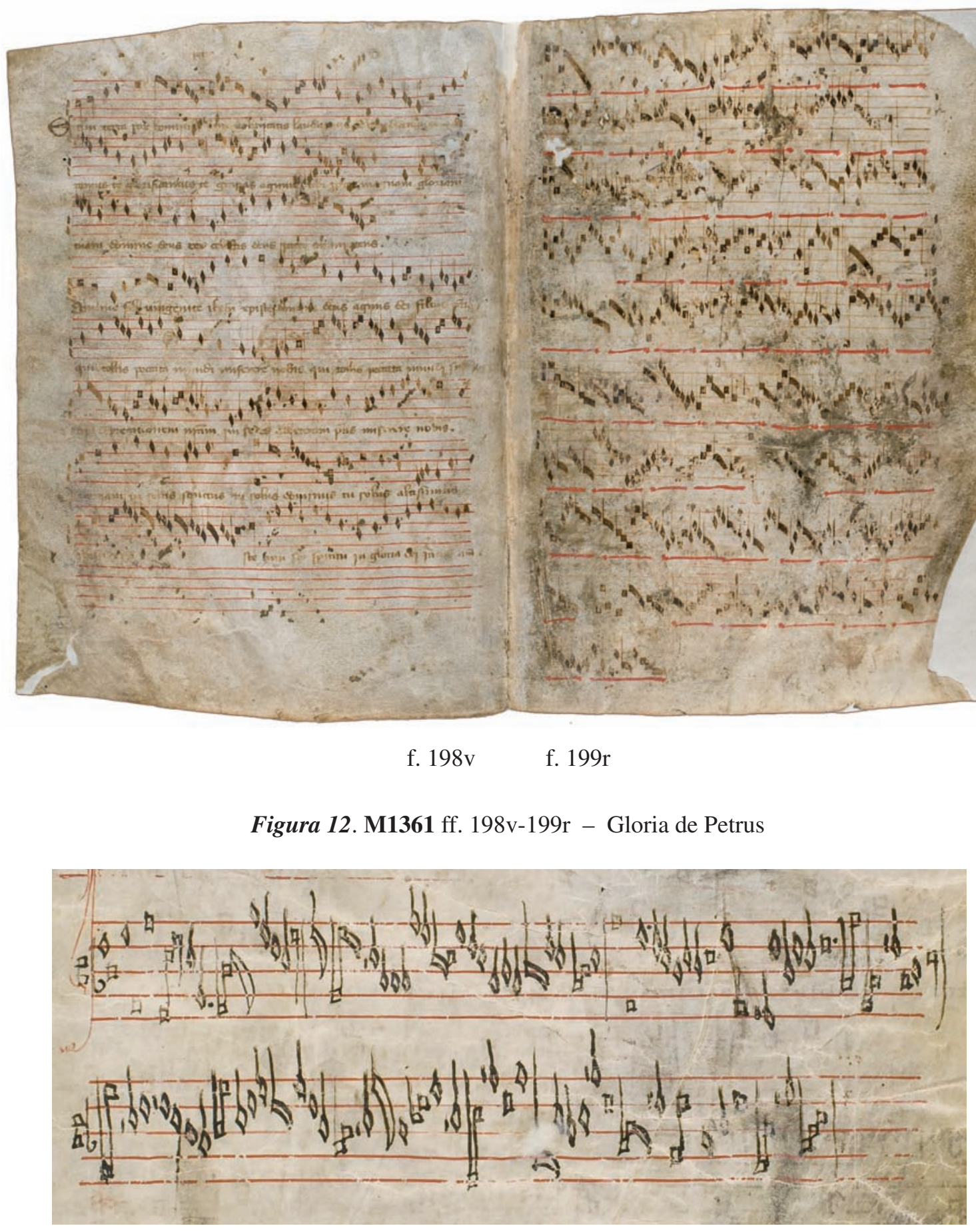

Figura 13. M1361 f. 197r - Fragmento sin texto. 

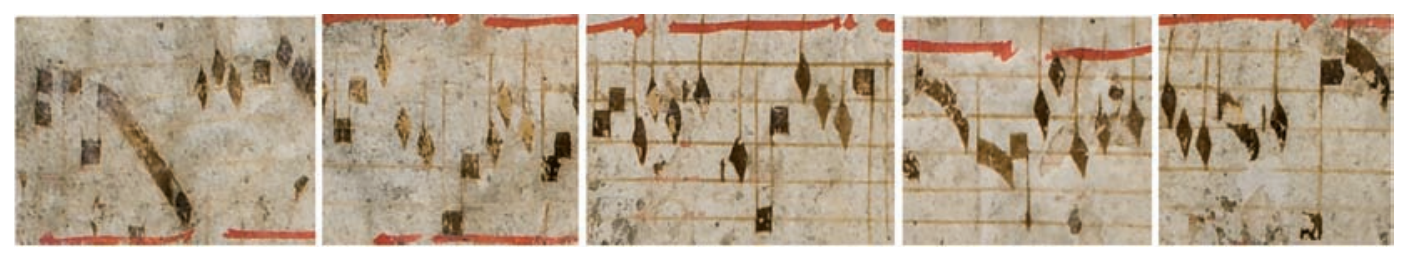

Figura 14. M1361 f. 199r - Gloria de Petrus (Contratenor)

Vale la pena detener la mirada unos instantes en el fragmento del folio 197r (una sola voz), al que Gómez se refiere simplemente como "fragment de musique sans texte, probablement instrumental". ${ }^{76} \mathrm{El}$ fragmento tiene todos los rasgos de un contratenor de una textura polifónica a tres voces, similar en estilo al Gloria de Petrus (ff. 198v-199r). Este tipo de contratenores se caracteriza por una figuración muy activa, repleta de saltos, en contraposición a un cantus más estable y un tenor melódicamente más lógico. Es interesante notar que está dividido en cuatro secciones; la última de ellas es la más larga y contiene secuencias isorrítmicas.

La presencia de este contratenor sugiere que en el entorno de M1361 circulaba mucha más música polifónica de la que este libro nos enseña. No parece que el escriba haya tenido la intención de copiar el resto de partes polifónicas. ${ }^{77} \mathrm{El}$ fragmento tiene más bien el aspecto de un apunte (para memorizarlo?), y/o tal vez testimonie la práctica de modificar o añadir nuevos contratenores a piezas preexistentes. El códice Mod A ofrece ejemplos de contratenores compuestos para sustituir a los de otras piezas bien conocidas, los cuales vienen transmitidos en solitario, es decir, sin el resto de partes polifónicas (cantus y tenor). ${ }^{78}$ 198].

76 Gómez Muntané, Maricarmen: op. cit. 1991 [aquí cito la versión de 1992 en L’Ars nova italiana del Trecento VI, p.

77 Su pautado rojo, trazado con regla, es prácticamente idéntico al de Iuste iudex (pieza que probablemente fue copiada con anterioridad). El escriba debió aprovechar un pautado vacío sabiendo que no quedaba suficiente espacio para copiar la pieza completa.

78 Por ejemplo Mod A 5v (nuevo contratenor para un rondeau de Machaut, Se vous nestes, probablemente compuesto por Matteo da Perugia) o Mod A 3v-4r (nuevo contratenor para una ballata de Bartolino da Padova, El non mezova). 
TABLA 4. Comparación entre el fragmento f. 197r y el Contratenor del Gloria f. 199r

\begin{tabular}{|c|c|c|}
\hline & f. 197r & f. 199r \\
Principio \\
(saltos in crescendo)
\end{tabular}
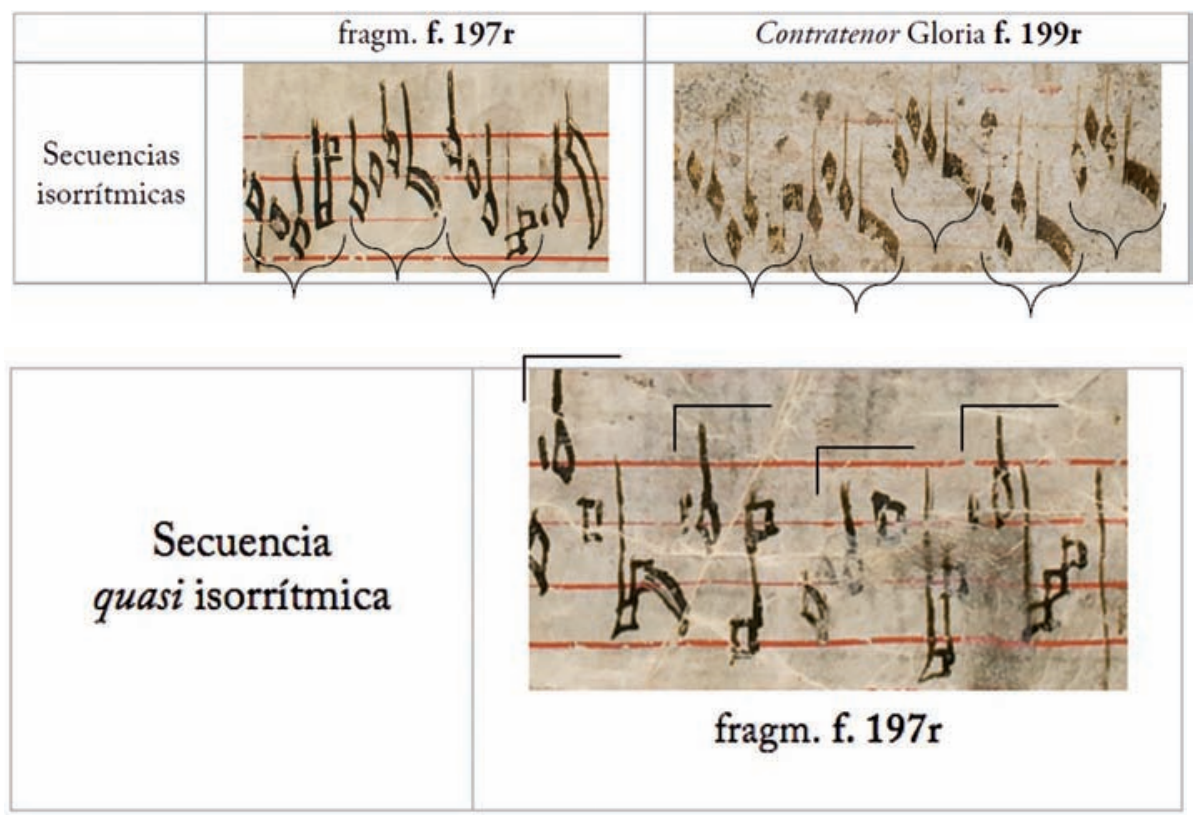


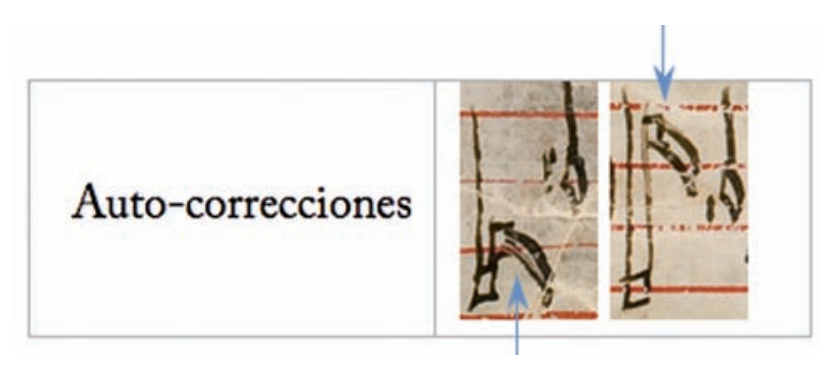

Por último, quisiera remarcar la existencia de algunos fragmentos palimpsestos que hasta el presente no habían sido notados. Varios fragmentos en notación blanca ocupaban el folio 197v antes de ser borrados para copiar la primera parte del Adoramus te Christe a 3 voces y los Alleluya monódicos In ferventis y Hic est vere. En la esquina superior izquierda de ese folio $(197 \mathrm{v})$ pueden observarse también los restos de un pequeño apunte en notación negra arsnovística (minimae, etc.). Finalmente, dos líneas de música sin texto (una en clave de Do y otra en clave de Fa) fueron borradas para copiar la segunda parte del Adoramus te Christe en f. 199r.

Ante la sospecha de que pudiera tratarse de un fragmento de polifonía, he tratado de transcribirlo iluminando el folio con radiación ultravioleta, lo cual me ha permitido observar con mayor claridad el cuerpo de las notas pero no la altura de los intervalos, ya que apenas se distinguen las líneas del pentagrama original. Su transcripción sólo ha sido posible mediante el empleo de tecnología digital y técnicas de restauración virtual, lo que me ha permitido descartar la posibilidad de que las dos líneas guarden una relación polifónica.

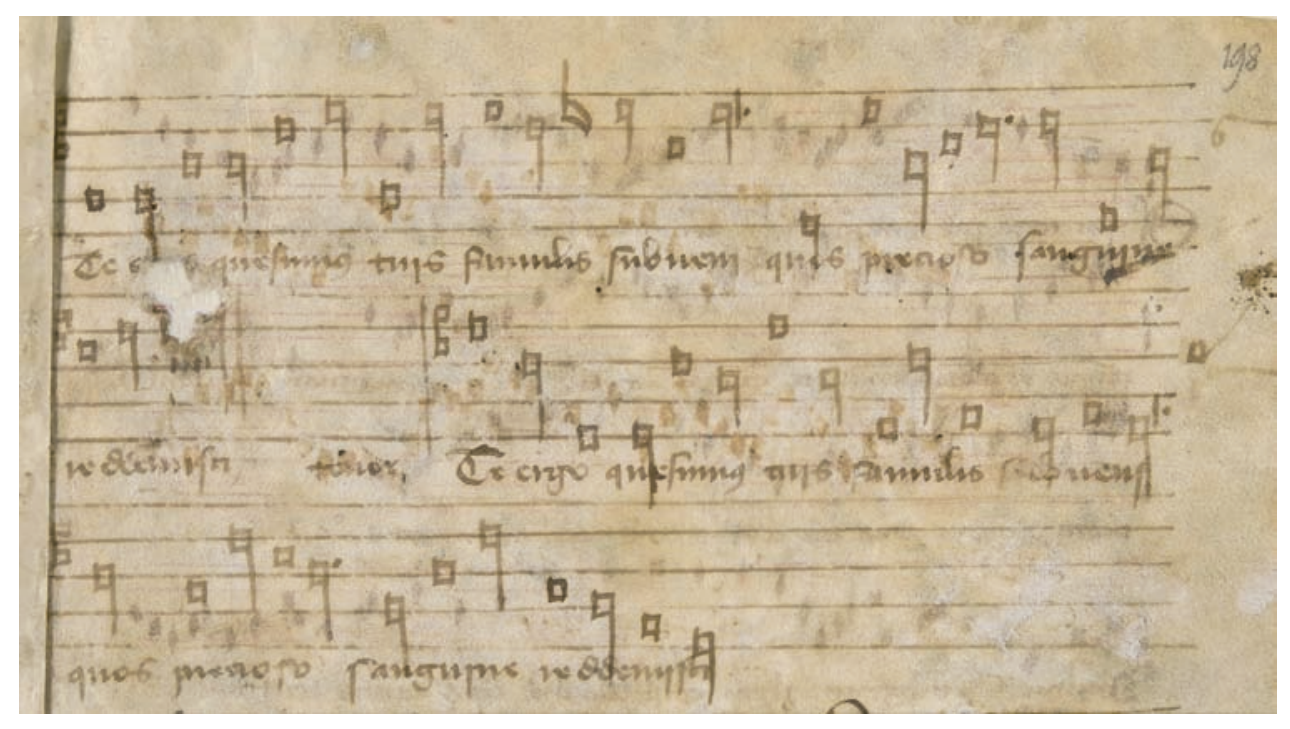

Figura 15. M1361 f. 198r - Continuación de ADORAMUS TE CHRISTE 


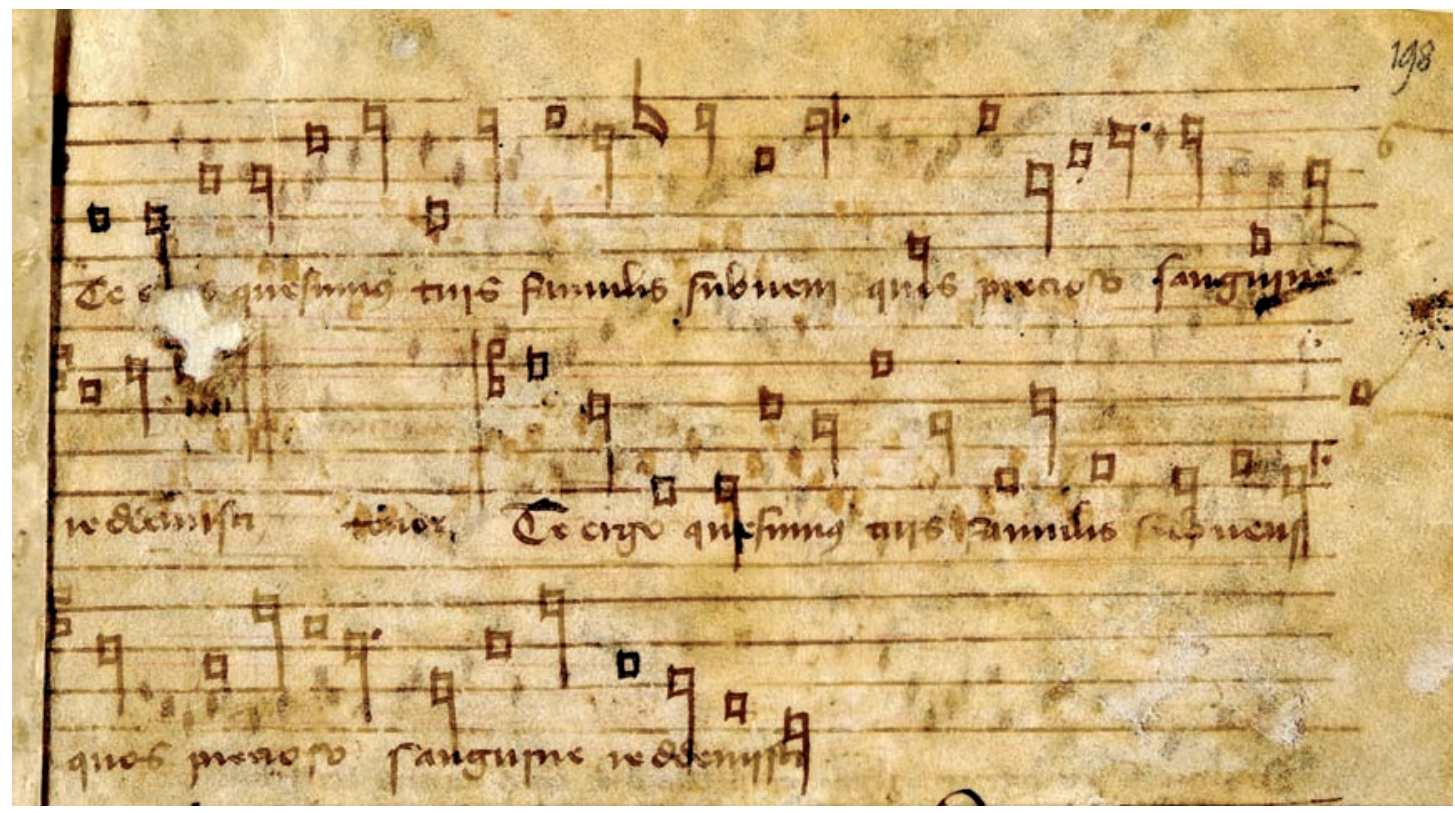

Aumento de contraste

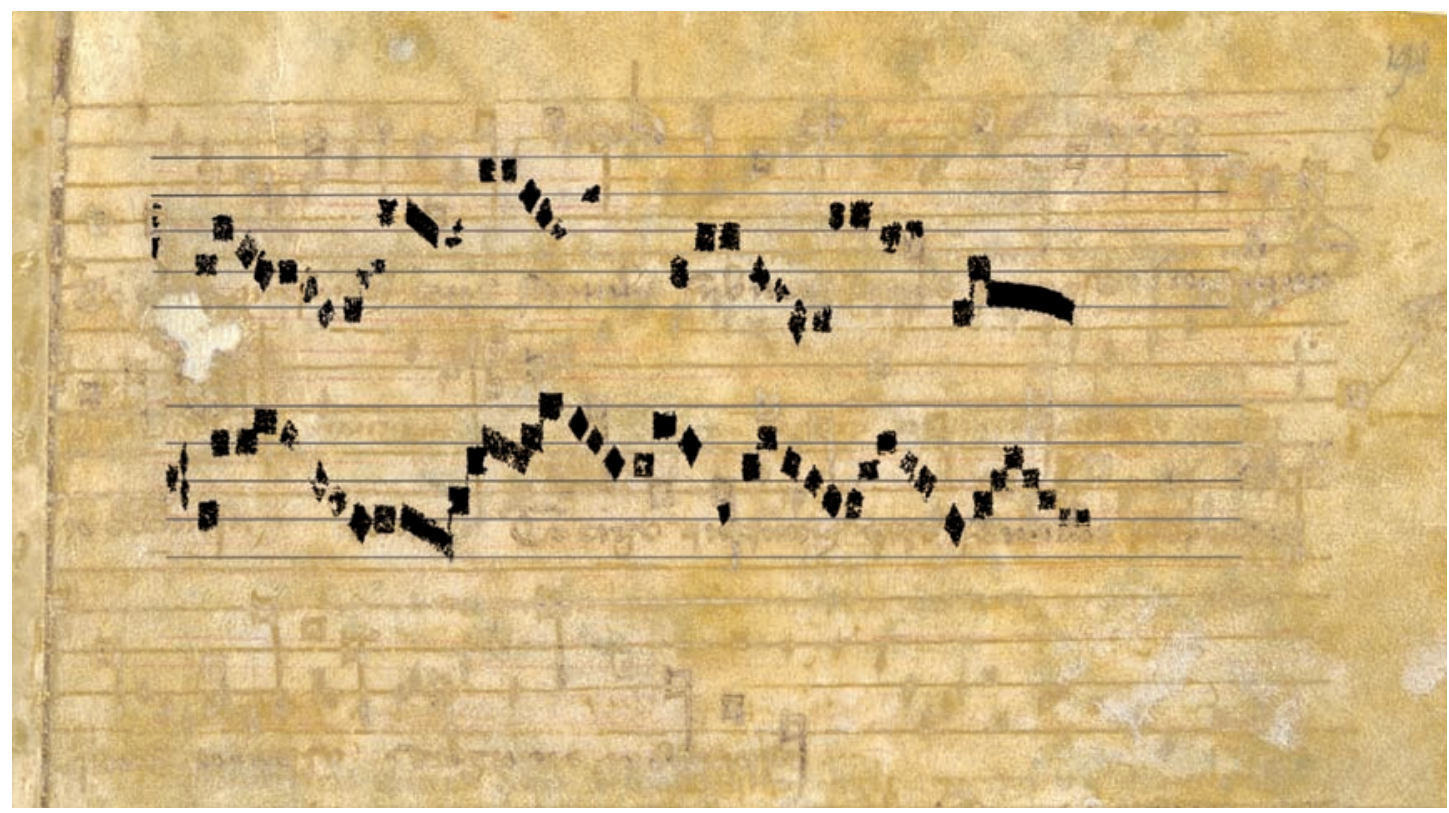

Restauración digital

Figura 16. M1361 f. 198r - Restauración virtual del Palimpsesto 


\section{ANEXO II: Revisión de algunas fuentes catalano-aragonesas}

Como ampliación de la nota a pié de página número 6, resulta pertinente justificar las observaciones mencionadas acerca de otras fuente de origen hispánico que en la literatura musicológica han sido citadas como 'Ars subtilior'.

\section{Barcelona, Biblioteca Nacional de Cataluña M853d f. 2r.}

El Amen de un Credo conservado en el manuscrito M853d de Barcelona (f. 2r) ha sido citado en varias ocasiones como un ejemplo de Ars subtilior procedente de la antigua Corona Catalano-Aragonesa. ${ }^{79}$ Desafortunadamente, este juicio se fundamenta en una transcripción errónea de Maricarmen Gómez Muntané, sobre la cual se basó la edición crítica de $P M F C{ }^{80}$

Aunque el Amen en cuestión no ofrece ninguna "complejidad rítmica" que lo aproxime al Ars subtilior, sí proporciona algunos problemas de transcripción, ya que la longitud de su cantus parece no coincidir exactamente con la del tenor y el contratenor (el cantus es una breve más corto que tenor y contratenor). Sin ninguna lógica crítica ni ninguna otra argumentación convincente, Gómez interpreta la notación roja como si indicara un cambio de medida (de $\odot$ a $\odot$, manteniendo el valor de la semibreve roja como perfecta), y no según su tradicional significado de imperfección para generar hemiolas (3 semibreves imperfectas en lugar de 2 perfectas), lo que produce que cada grupo de tres semibreves rojas mida un semibreve perfecta más de lo que debería. Esta curiosa interpretación de la coloración, lejos de solucionar el problema de la coordinación polifónica, lo complica mucho más, puesto que de esta manera ninguna de las tres voces coincide en longitud. En consecuencia, para poder encajar las tres voces, Gómez se ve obligada a realizar varias enmiendas. En primer lugar transcribe la ligadura cum proprietate et sine perfectione del tenor (breve-breve) como si fuera una ligadura cum opposita proprietate (semibreve-semibreve), con lo que lo acorta por valor de una breve. Seguidamente sustituye la última minima del cantus por una semibreve perfecta. El resultado de esta transcripción es un contrapunto sin sentido, lleno de disonancias y cuartas descubiertas, y en el que los movimientos cadenciales quedan descoordinados entre todas las voces (excepto la cadencia final, gracias a la 'enmienda' de la última minima del cantus).

Sin embargo, interpretando la coloración como hemiola prolationis, el contrapunto entre tenor y contratenor queda perfectamente coordinado de principio a fin sin necesidad de efectuar ni una sola enmienda, lo que claramente confirma que el significado de la notación roja es el tradicional. Además, el cantus encaja a la perfección con las otras partes hasta el décimo compás (que coincide con el cambio de línea del cantus).

79 El aparato crítico de PMFC (p. 490) se refiere a este Amen como "an interesting case of ars subtilior practice". Polyphonic Music of the Fourteenth Century. Maricarmen Gómez Muntané lo cita también en su libro La música medieval en España, Kassel, Reichenberger, 2001, como un ejemplo "cuya complejidad rítmica hace que se clasifique en el Ars subtilior", p. 251.

80 PMFC XXIIIB, p. 306, transcripción basada en GómEZ MunTANÉ, Maricarmen: La Música en la casa real catalanoaragonesa durante los años 1336-1432. Vol. II, Música. Barcelona, A. Bosch, 1979, p. 148. 
La descoordinación mensural del cantus en este último tramo del Amen podría deberse a un fenómeno conocido en la crítica textual como homoteleuton (saut du même au même). Si el último tramo del cantus original hubiese contenido dos figuras melódicas parecidas, el ojo del copista pudo saltar de una a otra dejando de copiar una de ellas por error. Esta hipótesis toma fuerza por el hecho de que las últimas 4 minimae del cantus (que configuran una cuarta descendente) encajan bien tanto en el $11^{\circ}$ como en el $12^{\circ}$ compás.

Otra solución, aunque quizás menos elegante, sería enmendar la pausa de minima del final del pentagrama del cantus como una pausa de breve. En el plano de lo estrictamente mensural la coordinación entre las voces quedaría resuelta, pero el contrapunto entre cantus y tenor no resulta convincente (séptimas paralelas), y la interrupción de la línea melódica con una pausa tan extensa resulta igualmente extraña.
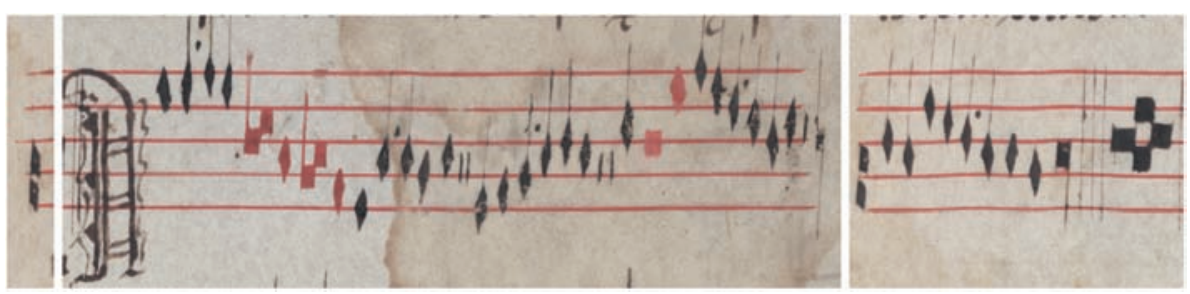

\section{Cantus}
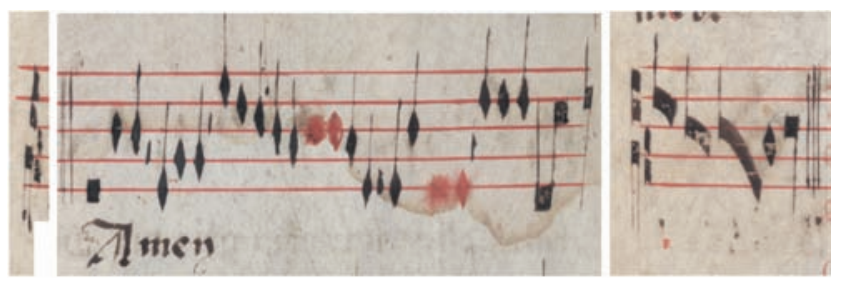

\section{Contratenor}

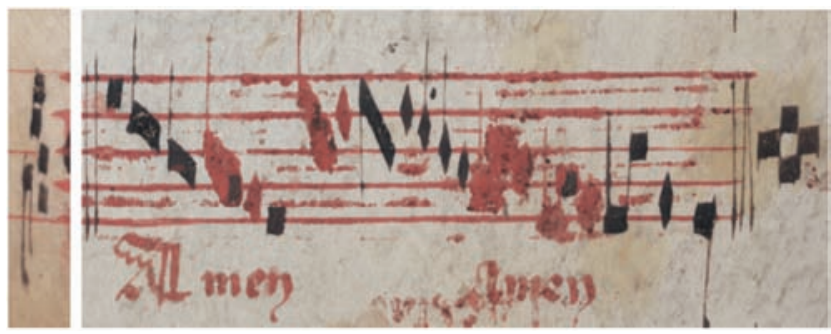

Tenor

Detalle Pausa en el Cantus

Figura 17: Barcelona Biblioteca de Cataluña M853d f. 2v - AMEN. 
EJEMPLO 2. M853d f. 2v (AMEN) - TRANSCRIPCIÓN DE PMFC

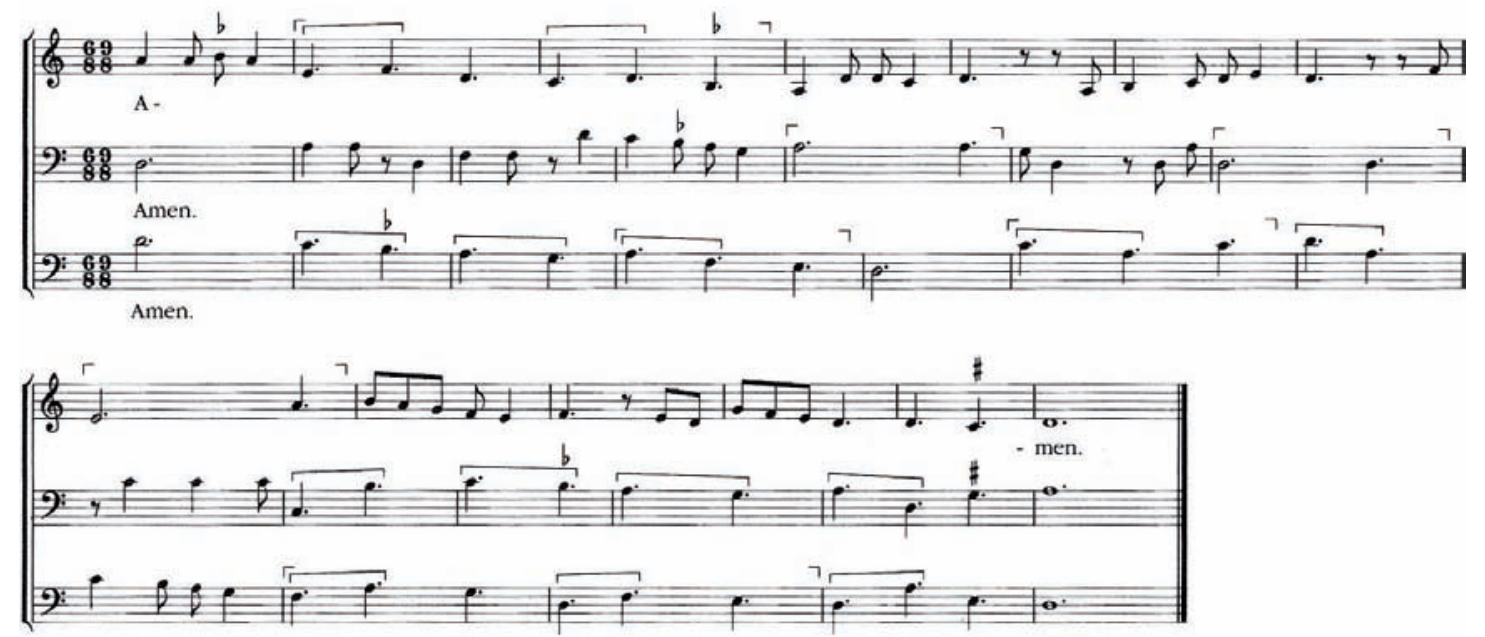

EJEMPLO 3. M853d f. 2v (AMEN) - TRANSCRIPCIÓN REVISADA

Posibilidad A: homoteleuton.

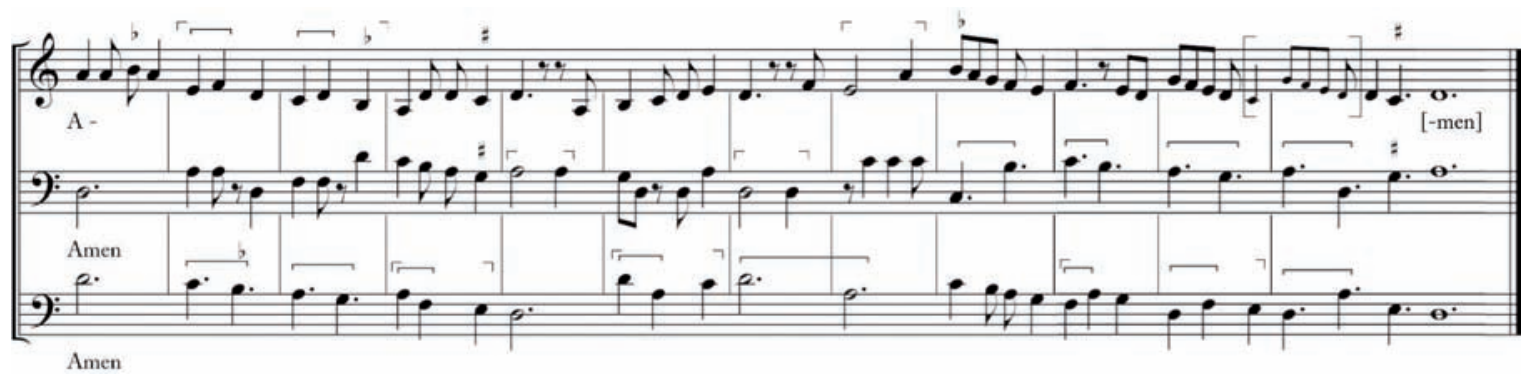

Posibilidad B: enmienda de la pausa.

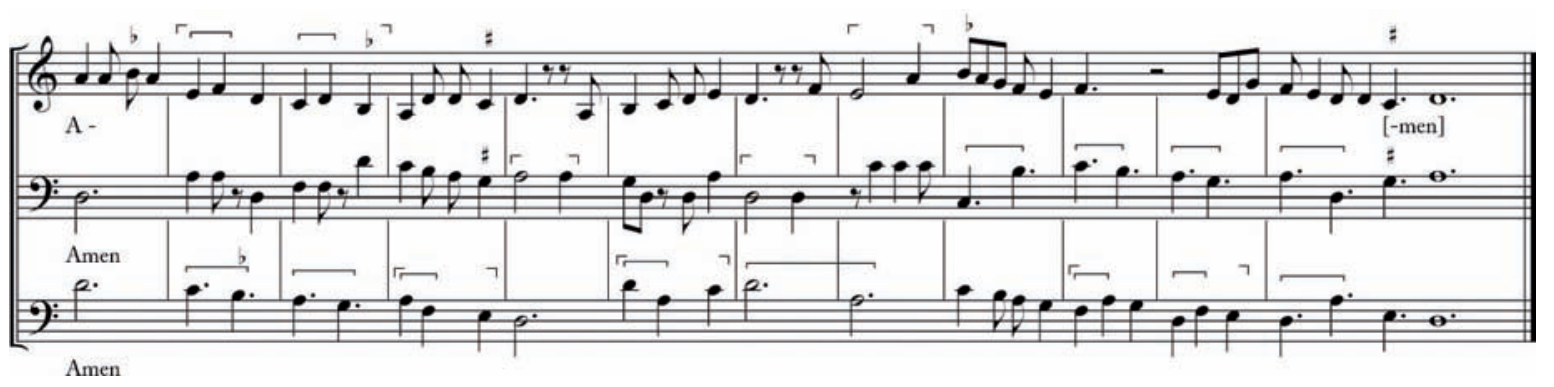




\section{Barcelona, Biblioteca Nacional de Cataluña M853 (Barc A) f. 2v}

Aparte del Amen del Credo de M1361, la única pieza conocida de procedencia española en la que se percibe alguna influencia del Ars subtilior es un Kyrie transmitido en el manuscrito fragmentario M853 de Barcelona (f. 2v). El manuscrito consiste en un solo bifolio que debió formar parte de un precioso fascículo de polifonía, destruido en siglos posteriores para reciclar su pergamino en la encuadernación de otros libros. El bifolio contiene dos motetes fragmentarios y tres movimientos de misa únicos, también incompletos. ${ }^{81}$

El Kyrie del folio 2v utiliza abundantes minimae y semiminimae en el cantus, rasgo más bien característico de un Ars nova tardío de corte italianizante. Su figuración es ciertamente rica y variada. Pero, el detalle que -según mi opinión- deja entrever una pequeña influencia de subtilitas se produce en el Christe, donde se superponen dos medidas distintas: el tenor continúa en $\odot$ mientras que el cantus cambia a $\subset{ }^{82}$ En principio esta 'polimensuralidad' no aporta mayores complicaciones rítmicas, hasta que en la sexto compás del Christe, un grupo formado por una semibreve y dos minimae se superpone a tres semibreves rojas del tenor, produciendo una relación rítmica en proporción 4 contra 3 a nivel de minima.

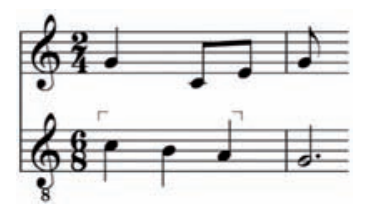

Igualmente interesante es el cambio de marcha que se produce al final del último Kyrie, con los cinco penúltimas mensuras coloreadas en el cantus.

Al tenor del Kyrie le sigue inmediatamente el tenor de un Gloria, del cual sólo se conserva esta voz. La similitud entre los tenores del Kyrie y el Gloria me hace sospechar que pudiera tratarse del principio de un ciclo unitario de misa, o al menos un par Kyrie-Gloria, ¿obra del mismo compositor? Resulta del todo sugestivo imaginar que el cantus de este Gloria haya podido tener la pintoresca figuración rítmica y melódica del Kyrie que le precede.

81 M853 es conocido sobre todo por transmitir una versión a cinco voces del célebre motete Apollinis eclipsatur. El manuscrito fue descrito por primera vez en 1925 por H. Besseler, quien le dio las sigla Barc A. BESSELER, Heinrich: "Studien zur Musik des Mittelalters I. Neue Quellen des 14. und beginnenden 15. Jahrhunderts" en Archiv für Musikwissenschaft, 1925 , vol. VII, pp. 167-252. Véase también Gómez Muntané, Maricarmen: "Une version a cinq voix du motet "Apollinis eclipsatur/Zodiacum signis' dans le manuscrit E-BCEN 853” en Musica Disciplina, 1985, vol. XXXIX, pp. 5-44.

82 Ninguna de las dos voces lleva signos mensurales ni proporcionales. El cambio de medida del cantus se deduce por su figuración rítmica, y que el tenor continúa en prolación mayor se deduce por el empleo de coloración roja, que indica imperfección (hemiolas de 3 breves imperfectas). 


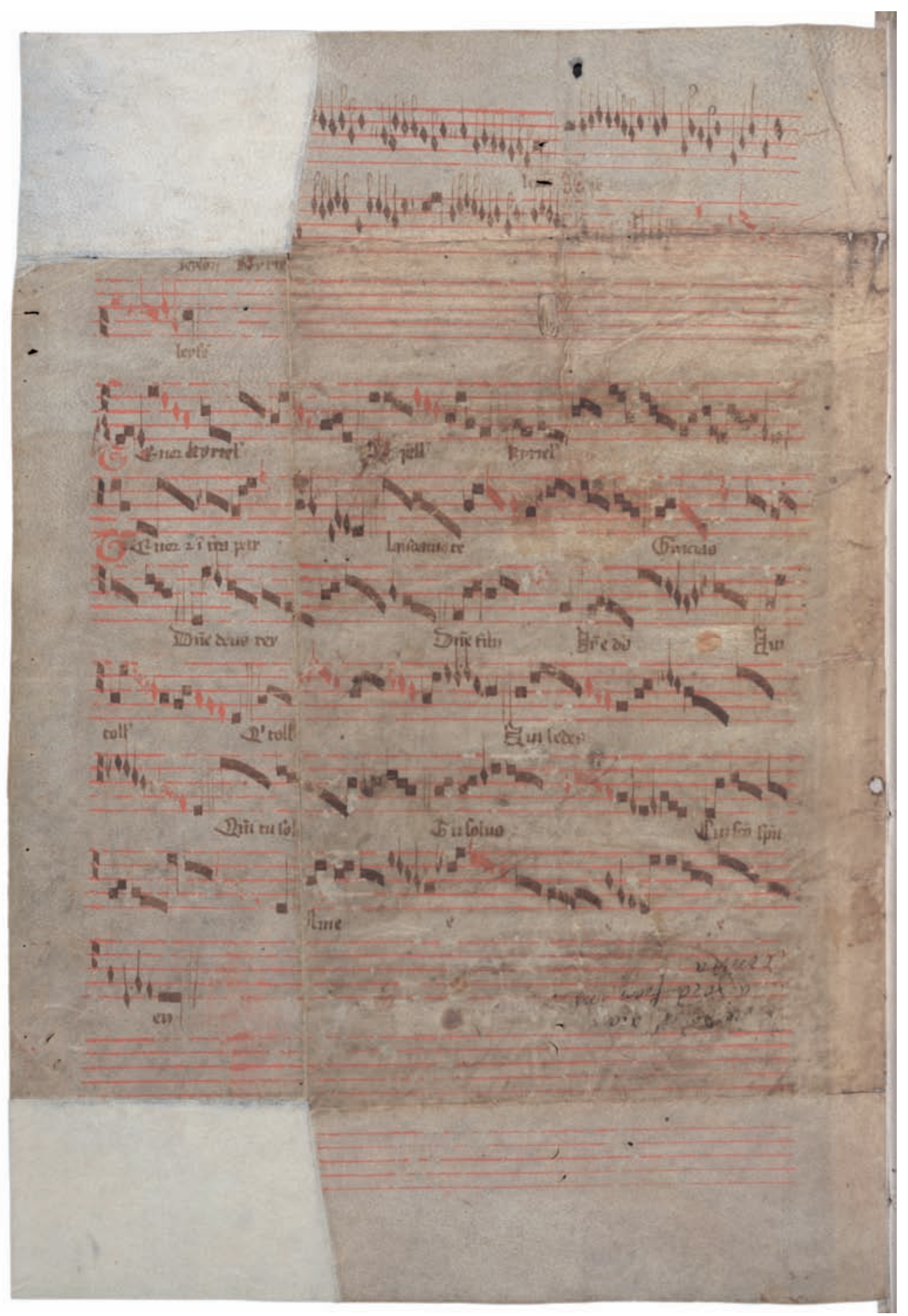

Figura 18. Barcelona Biblioteca de Cataluña M853 (BARC A) f. 2v. 
EJEMPLO 4. M853 (BARC A) f. 2v KYRIE - TRANSCRIPCIÓN
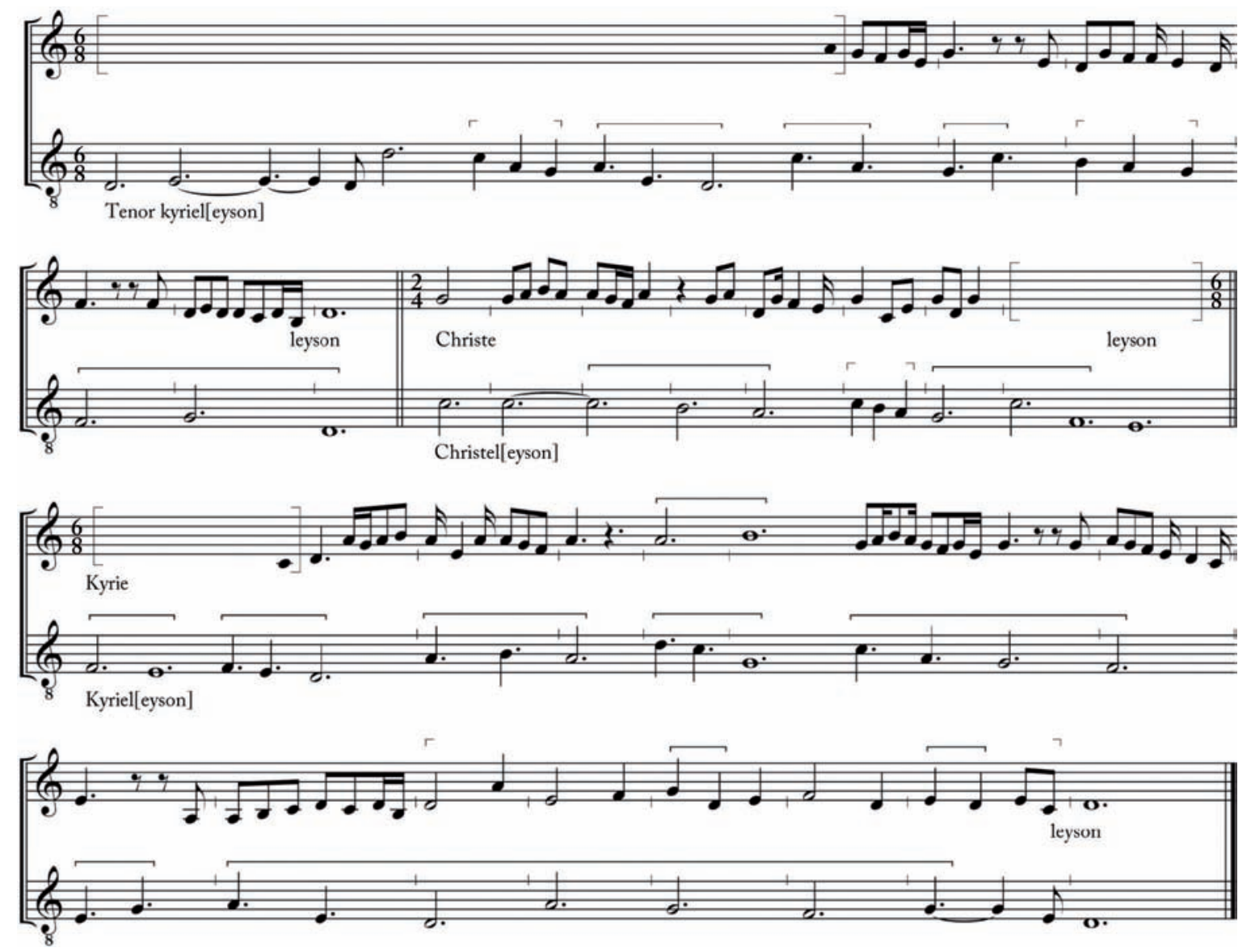

Recibido: 02/12/2010

Aceptado: 03/06/2011 